\title{
A Guerra do Chaco
}

\section{A. MONIZ BANDEIRA*}

O Brasil quase nada ganhou com a Guerra da Tríplice Aliança (18651870). Já unificado e centralizado como Estado-Império, com soberania sobre aproximadamente 8 milhões de $\mathrm{km}^{2}$ e uma população de 11 milhões de habitantes, apenas assegurou a abertura do Rio Paraguai à navegação, necessária ao abastecimento e à defesa da Província de Mato Grosso, e a anexação da área litigiosa entre o Rio Ugureí e a serra de Maracaju, rica em ervaçais, mas sem imediatos efeitos econômicos. O conflito custou-lhe, entretanto, sacrifícios que lhe desequilibraram as finanças por um quarto de século, conforme a previsão do Visconde de Mauá 1 . A fim de financiar a longa campanha contra as forças do Marechal Francisco Solano Lopez, o Governo Imperial tivera de gastar 600.000 contos-ouro, entre 1865 e $1870^{2}$, tomando à Casa Rotschild, em 1865, um empréstimo de $£ £ 6.963 .600$ e emitindo, até 1870 , cerca de 459.600 contos de reis ${ }^{3}$. O serviço da dívida externa passou desde então a consumir mais de $60 \%$, em escala crescente, do saldo que a sua balança comercial começara a apresentar, a partir de 1861, com o incremento das exportações de café para os E.U.A. ${ }^{4}$. E o Paraguai não teve sequer condições de pagar ao Brasil a dívida de guerra. Além de comprometer as finanças do Brasil, a Guerra da Tríplice Aliança também contribuiu para liquidar seu próprio sistema bancário, o mais adiantado e o único relativamente autônomo da América Latina ${ }^{5}$, ao prejudicar os negócios da Casa Mauá com a República do Uruguai. Conquanto se vinculasse às firmas Carruthers e McGregor, da GrãBretanha, o banco, que Irineu Evangelista de Souza, o Visconde de Mauá, possuía, representava uma espécie de embrião nacional do capitalismo financeiro, orientando seus vultosos investimentos para o esforço de industrialização, não só no Brasil como no Uruguai e na Argentina.

O Visconde de Mauá julgava “dever o Brasil exercer no Rio da Prata a influência a que lhe dá o direito sua posição de primeira potência na América do Sul”6 . Compreendia, no entanto, que uma "base econômica" e "não a da política exclusivamente" devia estear a preponderância sobre o Uruguai e que "cumpria estender a ação dessa influência ao outro lado do Rio da Prata"7 , i. e., à Argentina. Por esta razão o Banco Mauá, que criara no Brasil diversas empresas (fundição e estaleiro da Ponta de Areia, ferrovias, fábricas de tecidos, curtumes, etc), realizou inúmeros investimentos importantes tanto no Uruguai (frigorífico, telégrafo,

* Professor Titular de Política Exterior do Brasil da Universidade de Brasília. Aposentado. 
companhia de gás), quanto na Argentina, com a instalação de agências em Montevidéu, Salto, Paysandu, Mercedes e Cerro ${ }^{8}$. Por mais de 20 anos ele se tornou o agente financeiro daqueles dois países, a cujos governos concedeu vultosos empréstimos $^{9}$. Mas, a sofrer prejuízos no Uruguai, onde, desde 1865, enfrentara situações políticas adversas ${ }^{10}$, e a lutar, por causa da São Paulo Railway (Estrada de Ferro Santos-Jundiaí), contra a Casa Rothschild, o Banco Mauá não sobreviveu à Grande Depressão de 1874 e, um ano depois, pediu moratória, quando o Banco do Brasil, por estranha orientação do Governo Imperial, negou-lhe um empréstimo de 3.000 contos para atender ao pagamento de cambiais, entre as quais $£ £ 70.000$ a favor do Governo da Argentina, apesar da garantia dada com os títulos da Companhia Pastoril, no valor de 6.000 contos $^{11}$. A falência do Banco Mauá, três anos depois, concorreu para impedir que o Brasil, com as finanças depauperadas, tivesse condições de ocupar economicamente o Paraguai ${ }^{12}$, conquanto ainda lá mantivesse, por algum tempo, a influência política, reforçada, sobretudo, durante o Governo do General Bernardino Caballero (1880-1886) ${ }^{13}$. A Argentina, pelo contrário, fortalecera-se econômica e politicamente no curso da Guerra da Tríplice Aliança, não obstante as lutas civis que a convulsionaram naquele período, e que por mais alguns anos a afligiriam. Como as batalhas contra as forças do Marechal Francisco Solano Lopez ocorreram na mesopotâmia da Bacia do Prata, sem afetarlhe a produção e as atividades do comércio ${ }^{14}$, ela se convertera na principal fonte de suprimento dos exércitos aliados. As “enormes somas de dinheiro", despendidas pelo Brasil em Buenos Aires e em outras províncias da Argentina, "com mais prodigalidade do que discrição", possibilitaram aos seus habitantes a acumulação de grandes fortunas, conforme os diplomatas britânicos Edward Thornton e H.G. Lettson observaram ${ }^{15}$. A burguesia mercantil-financeira de Buenos Aires e os grandes estancieiros, que tratavam de construir e consolidar o Estado Nacional argentino, lançaram-se então à penetração econômica do Paraguai, uma vez que o Brasil não permitiria a sua anexação, propósito este mais ou menos entremostrado pelo Presidente Bartolomé Mitre e seu Ministro das Relações Exteriores, Rufino de Elizalde, quando das negociações do Tratado da Tríplice Aliança ${ }^{16}$.

Em 1870, quando a Guerra da Tríplice Aliança terminou, cerca de 16.239 léguas quadradas, de um total de 16.590, que constituíam o território paraguaio, pertenciam ao Estado; apenas 261 léguas quadradas estavam em mãos de particulares ${ }^{17}$. O Estado ainda possuía $72 \mathrm{~km}$ de ferrovia em funcionamento, 148 edifícios em Assunção e 352 em cidades e vilas do interior ${ }^{18}$. Mas logo em seguida o processo de privatização começou, a fim de possibilitar o pagamento das obrigações (Lei de 7.12.1870) e amortizar emissões de papel moeda, com o que todo aquele patrimômio, no curso de alguns anos, passou para o controle dos investidores de outras nações, particularmente da Argentina, da qual o Paraguai não apenas copiou a Constituição como adotou o próprio Código Civil. O historiador paraguaio Ricardo Caballero Aquino salientou que “a maioria dos especuladores 
estrangeiros, que chegaram ao Paraguai para investir em terras, vieram desde ou através da Argentina"19 e esta situação contribuiu para incrementar ainda mais a dependência do país em relação a Buenos Aires, cujos bancos e instituições financeiras começaram a receber e enviar grandes somas de divisas a Assunção ${ }^{20}$. Conforme outro historiador paraguaio, Efraim Cardozo, “a venda de terras públicas converteu os capitalistas argentinos nos maiores proprietários do país”21, sendo que a companhia La Industrial Paraguaya se apropriara de mais da metade das plantações de erva-mate, o mais importante item de sua pauta de exportações, e suplantara, vantajosamente, a Mate Laranjeira, a concorrente brasileira, afetada ainda mais pelas taxas alfandegárias ${ }^{22}$.

A mediterraneidade do Paraguai tornara inevitável a preponderância da Argentina, o principal mercado de consumo para os seus produtos, sobretudo a erva-mate, dado que ele só dispunha do Rio da Prata como única via de comunicação com o mundo e de acesso ao comércio internacional. Essa via dependia, exclusivamente, do porto de Buenos Aires.

O Brasil, cujas tropas se retiraram do Paraguai em 1876, tratou de conservar ainda sua influência política, favorecida sobretudo pelo Governo do General Bernardino Caballero (1880-1886), que fundou em 1887 o Partido Nacional (posteriormente denominado Associação Nacional Republicana), o Partido Colorado, para contrapor-se à emergência, naquele mesmo ano, do Partido Liberal, sob o nome de Centro Democrático. A disputa entre essas duas organizações refletia de certo modo a rivalidade entre o Brasil e a Argentina, que as instrumentalizaram e de cujas contradições elas também se valeram, a fomentarem no Paraguai um clima de contínua turbulência política. Embora cultuasse a memória do Marechal Francisco Solano Lopez, a reverenciá-lo como o herói da guerra, mártir da Pátria, vítima da Tríplice Aliança, o Partido Colorado alinhou-se com o Brasil e captou sua simpatia, dado que se apresentava como o baluarte da resistência às ambições territoriais da Argentina, cujo respaldo material (dinheiro, navios e armas) possibilitou, finalmente, a vitória de uma revolução, dirigida pelo Partido Liberal, em $1904^{23}$.

O Governo do então Presidente Juan Antonio Escurra (1902-1904) contava com o apoio do Brasil, cuja simpatia ganhara quando evitou o aumento das tarifas sobre o trânsito da erva-mate e permitiu a liberdade de emigração daqueles que quisessem trabalhar no território brasileiro. Porém, mais incompetente do que todos os seus predecessores do Partido Colorado, afigurava-se instável e a Legação da Grã-Bretanha em Assunção, já em julho de 1904, previa e esperava que a revolução ocorresse, para derrubá-lo ${ }^{24}$. Com efeito, um mês depois, ela eclodiu, sob o comando do General Benigno Ferreira, acusado de envolvimento com Henry White, gerente local da Paraguay Central Railway, que, aliás, confiava na sua vitória para resolver problemas pendentes da companhia ${ }^{25}$. 
Cerca de 300 revolucionários, por volta do dia 10 de agosto, apossaram-se do navio mercante Sajonia, nele instalaram uma bateria de seis canhões Krupp e, com 2.000 fuzis Remington, adentraram o rio Paraguai, dominando seu curso e capturando cidades e postos ao sul de Assunção ${ }^{26}$. O Vice-Presidente da República, Manuel Dominguez, rompeu então com o Governo Escurra, aderindo à revolução, cujas causas, o Cônsul da Grã-Bretanha em Assunção, Cecil Gosling, observou, eram de natureza mais intrincada do que geralmente se supunha uma vez que os Estados vizinhos - Argentina, Brasil e Bolívia - estavam mais envolvidos na contenda do que à primeira vista se afigurava ${ }^{27}$.

Segundo ele, a salientar que boas razões havia para crer que o crédito dos revolucionários fosse o mais amplo em Buenos Aires, a queda do Governo Escurra, com toda a probabilidade, significaria moralmente o protetorado da Argentina sobre o Paraguai e, como os cofres de Assunção estavam vazios, a obtenção de empréstimos exteriores tornar-se-ia matéria de imediata necessidade ${ }^{28}$. Tanto em Buenos Aires quanto em Assunção, os círculos diplomáticos estavam convencidos de que o Governo argentino sustentava aquele movimento sedicioso e que se orientava no sentido da anexação do Paraguai ${ }^{29}$. A parcialidade ostensivamente se manifestara. Ainda que os revolucionários não tivessem os direitos de beligerantes, o Governo argentino medida nenhuma tomou para reprimir, nos rios da Bacia do Prata, as ações qualificadas de pirataria, tais como a captura e revista de navios mercantes ou de passageiros, que se destinavam ao porto de Assunção ${ }^{30}$. Um paquete brasileiro, procedente de Mato Grosso, detido foi pela flotilha rebelde, em frente de Concepción, e revistado com grande aparato de força ${ }^{31}$.

Diante daquelas circunstâncias, o Brasil enviou dois navios de guerra República e Carioca - ao porto de Assunção e, depois, deslocou o cruzador Tiradentes e dois navios - Fernandes Vieira e Antonio João - para o rio Paraguai, onde a Argentina estacionara uma flotilha maior ${ }^{32}$. E o Barão do Rio Branco, então Ministro das Relações Exteriores, pediu a interferência dos EUA. Instruiu o Chefe da Legação do Brasil em Washington, Ministro Plenipotenciário Alfredo de Moraes Gomes Ferreira, que insinuasse “discretamente” a John Hay, Secretário de Estado do Presidente Theodore Roosevelt, a "conveniência” de mandar um ou dois navios de guerra ao Paraguai, a fim de prestigiar o Governo legal, impedir os abusos dos revolucionários contra os navios mercantes e induzi-los a aceitar condições razoáveis de pacificação ${ }^{33}$. Os EUA recusaram-se a tomar qualquer iniciativa, a alegarem a distância como pretexto, mas o fato é que o Presidente Theodoro Roosevelt já expressara certa simpatia pela Argentina, ao proclamá-la como a nação eleita "para sustentar a Doutrina Monroe na América do Sul, devido às suas "condições de progresso e raça" 34 .

À frente do Corpo Diplomático, o Ministro Plenipotenciário do Brasil, Itiberê da Cunha, realizou renovadas gestões, com o objetivo de obter para o conflito uma solução conciliatória, favorável ao Presidente Escurra. Não teve êxito. O General 
Benigno Ferreira exigira indicação de um membro do Partido Liberal para a Presidência do Paraguai e não aceitou qualquer entendimento. O Brasil, porém, não se dispunha a correr o risco de uma guerra contra a Argentina, como aparentemente os paraguaios pretendiam provocar. Na verdade, o Brasil não tinha condições de entrar em um conflito armado. Ainda não reconstruíra sua esquadra, enfraquecida desde a revolta da Armada de 1893. Perdera a supremacia, como a maior potência militar da América do Sul, que antes fora, para a Argentina e o Chile. A Marinha brasileira encontrava-se em uma situação bastante precária, tanto ao nível de pessoal quanto de armamento ${ }^{35}$. O número absoluto de marinheiros caíra, na primeira década da República, para níveis inferiores aos do tempo do Império. Sua esquadra, em 1902, apoiava-se tão somente em quatro navios, os únicos que, entre 51 unidades navais, podiam efetivamente entrar em operação. $E$ a situação do Exército não era muito melhor, devido a fatores de política interna e às dificuldades financeiras, em que o Brasil se empenhara depois da proclamação da República (1889), embora sua reorganização começasse, a partir de 1900. Destarte, o Governo brasileiro não tinha interesse em uma confrontação com a Argentina e se recusou a enviar a ajuda solicitada pelo Presidente Escurra, que, apesar de escorado pelos dois maiores líderes do Partido Colorado, os Generais Bernardino Caballero e Patrício Escobar, não contou com meios para resistir à guerra de desgaste promovida pelo General Ferreira e à crescente insatisfação popular em todo o país. No dia 12 de dezembro, quatro meses depois de iniciada a revolução, Escurra, a bordo do navio argentino La Plata, firmou com o General Ferreira o tratado de Pilcomayo, mediante o qual resignou à Presidência do Paraguai em favor de Juan Bautista Gaona, levando ao poder o Partido Liberal ${ }^{36}$. O Cônsul da Grã-Bretanha em Assunção, Cecil Gosling, observou então que a queda do Governo Escurra e a ascensão ao poder do Partido Liberal, após uma luta que se arrastara por mais de vinte anos, constituía considerável triunfo da diplomacia argentina ${ }^{37}$. Afigurou-se-lhe então que o Brasil perdera prestígio e influência, e a mudança nos papéis que ele e a Argentina até então desempenharam seria “vantajoso" para o Paraguai, cujo novo Governo se mostrava imbuído de "idéias modernas de civilização e de progresso"38 . Conforme o historiador norte-americano Harris Gaylord Warren, posteriormente, observou, enquanto o Brasil nada fez para perpetuar sua influência, a Argentina patrocinou a revolução e o Paraguai, arrastado de volta para sua órbita, nela, como um "satélite”, permaneceria por muitas décadas ${ }^{39}$.

A vitória, pelas armas, do Partido Liberal ajustou, na realidade, o Governo do Paraguai ao poder econômico e à nova correlação de forças na Bacia do Prata. Ela decorreu da preeminência alcançada pela Argentina, que se tornara mais próspera e poderosa do que o Brasil e adquirira condições de projetar externamente a vontade social de suas classes dominantes, uma vez estabilizada a política interna e consolidado o Estado nacional. Afinal, já era a partir de Buenos Aires que os 
interesses argentinos, entrançados intimamente com os capitais ingleses, controlavam a economia do Paraguai, onde o Brasil nenhuma firma possuía que se comparasse à Carlos Casado Ltda, à Paraguay Central Railway ou à Anglo Paraguay Land Co. ${ }^{40}$

Assim, o êxito da revolução de 1904, de acordo também com a percepção do historiador Caballero Aquino, "implicou o predomínio da influência argentina nos assuntos paraguaios" 41 . E este predomínio se ampliou cada vez mais, embora a política interna não se estabilizasse e evoluísse para uma situação próxima da anarquia, sem que a República sequer se democratizasse. Uma série de quarteladas, golpes de Estado e revoluções começou, com o Partido Liberal a dividir-se em facções que lutavam entre si pelo poder. Desde então, nenhum Presidente do Paraguai, cujos governos não foram menos autoritários do que os dos seus predecessores do Partido Colorado, completou o mandato de 4 anos, estabelecido pela Constituição de 1870. Juan Batista Gaona não permaneceu mais que um ano na Presidência do Paraguai. Caiu em 9 de dezembro de 1905, derrubado pelos seus companheiros, integrantes da facção dos Liberais Cívicos, cujo “óbvio argentinismo" levava-os a falar "con cierto acento rioplatense"42, e Cecil Baez, ideólogo do liberalismo, substituiu-o, a fim de preparar as eleições e entregar o poder ao próprio General Benigno Ferreira, chefe militar da revolução de 1904. Este, eleito em 1906, não demorou no governo mais do que dois anos. Sob a acusação de pender demasiadamente para o lado da Argentina, teve de renunciar à Presidência da República, em 2 de julho de 1908, após sangrento levante chefiado pelo Coronel Albino Jara, seu ex-companheiro de armas, durante a revolução de 1904, e pertencente à facção radical do Partido Liberal. O Vice-Presidente, Emiliano Gonzáles Navero assumiu o governo, também por um brevíssimo período, bem como sucessores, Manuel Gondra e o próprio Coronel Jara, dado que as sublevações e os golpes de Estado não cessaram, mantendo o país em permanente turbulência, enquanto os navios de guerra do Brasil e da Argentina transitavam pelas águas do rio Paraguai, a respaldarem, aberta ou veladamente os bandos em conflito.

A desvantagem econômica, política e estratégica do Brasil, na região, era, porém, enorme. A Argentina, que possuía a maior extensão de vias férreas por habitante e, em valor absoluto de quilômetros, só perdia para os E.U.A., Alemanha, Grã-Bretanha, França e Áustria, assenhoreara-se, na Bacia do Prata, de todos os canais profundos, pelos quais as grandes embarcações, que demandavam Buenos Aires, trafegavam ${ }^{43}$. O Rio da Prata constituía sua rota comercial, por excelência, e o exercício do condomínio de suas águas, por parte do Uruguai, não passava de "simples ficção jurídica", sem base na realidade ${ }^{44}$. Os rios Paraguai, Paraná e Uruguai estavam, igualmente, sob o controle da Argentina, dado que o Brasil lá não possuía nenhuma base naval importante e seus navios mercantes perderam a concorrência para os daquele país, já senhores de toda a Bacia do Prata. Segundo a percepção do diplomata brasileiro Ronald de Carvalho, $1^{\circ}$. oficial do gabinete do 
Chanceler Octávio Mangabeira, o Paraguai, em 1927, era uma "verdadeira província" ou uma espécie de "feudo" da Argentina, a ela atrelado pelo Tratado de Comércio de 1916, que estatuíra um regime de franquias e sanções alfandegárias, a permitir o livre comércio entre os dois países ${ }^{45}$.

Os grupos econômicos, sediados em Buenos Aires e que também possuíam grandes interesses na Bolívia, onde adquiriram considerável faixa de suas melhores terras $^{46}$, espraiaram de tal modo seu domínio que o Chaco ficou de fato sob controle da Argentina, apesar de que, após a Guerra da Tríplice Aliança, o Brasil impedisse que o Paraguai lhe cedesse de jure a soberania sobre a região. A firma Casado \& Cia., além das atividades ligadas à produção e comercialização de tanino, dedicarase à criação de gado. Fundada por volta de 1886, quando Carlos Casado passara de Buenos Aires para Assunção e comprara, no Chaco, 3.000 léguas de terra, expandira tanto suas operações que, no início dos anos 30, possuía cerca de 134 $\mathrm{km}$ de estrada de ferro dentro de sua propriedade ${ }^{47}$.

A Soc. Puerto Peñasco, a Soc. Indústrias de Quebraixo e outras, bem como todas as empresas empenhadas na extração do mate, pertenciam totalmente a capitais da Argentina, cuja sucursal do Banco da Nación, em Assunção, apresentava um movimento financeiro maior do que o de todos os bancos estrangeiros reunidos ${ }^{48}$.

O Brasil não se conformou, naturalmente, com a completa perda de influência sobre o Paraguai e acompanhou com profunda suspicácia o impulso dado pela Argentina ao seu plano de comunicações com a Bolívia, mediante a ligação direta Buenos Aires-La Paz e construção de duas transversais ferroviárias do Chaco Meridional: Embarcación-Formosa e Metan-Resistencia. Segundo a percepção do Governo brasileiro, ela, já a predominar sobre o Paraguai, voltara suas vistas para a Bolívia, que, depois de 1904, a política do Chile estava a atrair para o Pacífico. O temor do Estado-Maior do Exército, bem como do Ministério das Relações Exteriores, era de que a Argentina, a dispor de importantes recursos (petróleo, gado e cereais), boa organização econômica e constituindo, na América do Sul, "potência de primeira grandeza", com "superioridade militar terrestre, marítima e aérea”, sobre o Brasil, tentasse absorver a Bolívia, além do Uruguai e do Paraguai, e assim recompor as fronteiras do Vice-Reino do Rio da Prata ${ }^{49}$.

E o alarme ainda mais aumentou quando o Governo de Buenos Aires conseguiu que o de La Paz firmasse o Protocolo Carrillo-Gutierrez, que lhe dava a concessão para o prolongamento ferroviário de Yucuiba e Santa Cruz de la Sierra, com a facilidade de construir ramais transversais para o Chaco e Puerto Suarez ${ }^{50}$. O Itamaraty tratou então de frustrar sua aprovação, uma vez que, se efetivada, impediria qualquer prolongamento da rede ferroviária brasileira através daquela região.

O Protocolo Gutierrez-Carrillo, com a Argentina, contrapunha-se, por conseguinte, aos compromissos oriundos do Tratado de Petrópolis, de 17 de 
novembro de 1903, pelo qual, a resolver com a Bolívia o litígio sobre o Acre, o Brasil se obrigava a construir, em seu próprio território, por si ou por uma empresa particular, uma ferrovia, desde o Porto de Santo Antônio, no rio Madeira, até GuajaráMirim, no Mamoré, com um ramal, que, passando por Vila Murtinho ou outro ponto próximo (Estado de Mato Grosso), chegasse à Villa Bella (Bolívia), na confluência com o Beni ${ }^{51}$. Esta ferrovia não só visava a desviar para o Atlântico, através do Madeira, todo o comércio das regiões do Beni, Madre de Dios e Orton, na Bolívia, e facilitar a ligação com La Paz, como tinha igualmente o objetivo de reduzir e eliminar a dependência em relação aos rios da Bacia do Prata, que tornava bastante vulneráveis o transporte de mercadorias e as comunicações com os Estados de Mato Grosso, Goiás, parte de São Paulo e Paraná, no oeste brasileiro. Sua construção, já tentada, desde 1874, pelo Coronel norte-americano George Earl Church, começou, oficialmente, em 1907 e as obras - a extensão dos trilhos por 364 km até Guajará-Mirim - só terminaram cinco anos depois, em 1912, a um custo de milhares de mortos, vitimados pela malária, flechas, feras e outras adversidades das selvas. O ramal até Villa Bella não foi estendido porque, nesse ínterim, a Bolívia, em conseqüência da queda do preço da borracha no mercado internacional, manifestou ao Brasil interesse na modificação do seu traçado, objeto então de três protocolos (1901, 1912 e 1925), que malograram, levando os dois países a, em 25 de dezembro de 1928, celebrarem o Tratado de Limites e Comunicações Ferroviárias. E qualquer avanço na execução do projeto não houve. Pelo contrário, o projeto que conforme o Protocolo de 1925 fixara, visava à ligação Corumbá - Santa Cruz de la Sierra, substituído fora por outro, de importância econômica inferior, ao mesmo tempo em que impunha à Bolívia o compromisso de executar “um plano de construções ferroviárias”, tão difuso quanto irrealizável, porquanto ela não dispunha dos recursos necessários à consecução de semelhante empreendimento ${ }^{52}$.

De qualquer forma, até o início dos anos 30, o Brasil não concretizara a ligação Corumbá - Santa Cruz de la Sierra, propiciando à Bolívia efetiva saída para o Atlântico e libertando-a da dependência em relação ao Rio da Prata e ao porto de Buenos Aires, conforme o espírito do Tratado de Petrópolis, de 1903. Por meio deste Tratado, o Brasil também lhe concedera o triângulo de terras ao norte da Bahia Negra e outras saídas para o Paraguai, Mandioré, Gaiba e Uberaba, o que lhe compensou a perda de Puerto Pacheco (Bahia Negra), conquistado, em 1888, pelo Estado paraguaio, a assenhorear-se de toda a margem daquele rio. Contudo, quando, em 1928, as refregas por causa do Chaco recomeçaram e tropas do Paraguai acometeram o Fortim Vanguardia, a Bolívia também perdeu esse triângulo de terras, ao sul do Fortim Coimbra, com o que ainda mais recalcada foi na sua mediterraneidade.

O Chile, que lhe arrebatara, durante a guerra de 1879-83, o litoral do Pacífico, a ela assegurara, com o Tratado de Paz de 1904, o trânsito ferroviário, através do 
deserto de Atacama, já sob sua jurisdição. Esta franquia, porém, não podia reparar a mutilação do território nem as frustrações daí decorrentes. Destarte, sem o litoral do Pacífico, não mais dispondo, igualmente, de acesso à Bacia do Prata e ainda impossibilitada de alcançar o Atlântico, por via ferroviária, a Bolívia, em meio de forte depressão econômica desencadeada pela crise de 1929, decidiu recuperar a passagem através da Bacia do Prata dado que considerava parte do seu território a margem direita do rio Paraguai, onde os paraguaios, a avançarem por toda a zona ribeirinha, pertencente ao Departamento de Tarija, próxima do Fortim Olimpo e quase em contato com o Departamento de Chuquisaca, construíram quatro portos: Pinasco, Casado, Sastre e Guarany ${ }^{53}$. Ela se julgava mais bem armada, mais forte, militarmente, que o vizinho, com o qual disputava o território, e, conforme as palavras do Embaixador Antônio Salum-Flecha, “desengañada de sus anteriores tentativas diplomáticas para obtener una salida sobre el rio Paraguay, inició una nueva política como medio efectivo de incorporar el Chaco a sus domínios consistentes en una penetración pacífica" 54 .

Esta política o Presidente Daniel Salamanca (1931-1935) se dispôs a executar com determinação quando assumiu, em 1931, o Governo da Bolívia, e propôs ao Estado Maior do Exército que elaborasse um plano para "penetração pacífica”, ocupação militar e exploração do Chaco ${ }^{55}$. Seu propósito era "prestar maior atenção" a esta questão, devido não só à honra como ao "supremo interés del porvenir de Bolivia, tanto para asegurar sus territórios del sudeste, constantemente usurpados, como para abrirse una salida al Plata"56 . Inevitável, portanto, o agravamento do conflito se tornava. A Bolívia, em meados de 1931, tomou a iniciativa de suspender novamente as relações diplomáticas com o Paraguai ${ }^{57}$. Poucos meses depois, em setembro, tropas bolivianas, com ordem de ocupar os lugares providos de água, tomaram o posto avançado paraguaio Masamaklay, rebatizado Água Rica. E as refregas recresceram e se generalizaram, em 1932, quando o regimento Lanza, sob o comando do Major Oscar Moscoso, capturou o Fortim Antônio Carlos López, na verdade, um rancho que albergava insignificante guarnição de 1 cabo e 5 soldados $^{58}$, à margem da laguna Pitiantuta, ou Chuquisaca, cuja importância consistia no fato de constituir o único reservatório de água, em muitas léguas ao longo da região. A guerra do Chaco, formalmente, começara.

O jornalista brasileiro Lindolfo Collor, que logo após a Revolução de 1930 fora o Primeiro Ministro do Trabalho do Governo de Getúlio Vargas (1930-1945), escreveu, naquela época, um artigo para La Prensa, de Buenos Aires, no qual assinalava que a Guerra do Chaco não se ajustava de nenhum modo ao conceito de bellum, pois se distinguia de todas as outras guerras, porque, juridicamente, não teve começo e, militarmente, não teria fim ${ }^{59}$. Segundo ele, a guerra, "latente ou implícita”, sempre fora o "elemento primordial de civilização, um status social, no Chaco, onde o latifúndio teve e ainda tinha um "fulgor jamás sobrepasado o siquiera alcanzado" em qualquer região do mundo ${ }^{60}$. Com efeito, o Chaco, palavra, 
aparentemente de origem quíchua, compreendia vasta planície, encravada na mesopotâmia da Bacia do Prata, ao centro-sul do continente, e dividida, dada a sua extensão, em três regiões: Chaco Boreal, Chaco Central e Chaco Austral. A disputa pelo seu domínio começou nos meados do século XIX, quando Juan de la Cruz Benavente, Encarregado de Negócios da Bolívia em Buenos Aires, protestou contra a celebração do Tratado de Navegação e Limites de 15 de julho de 1852, pelo qual a Confederação Argentina reconheceu a soberania do Paraguai sobre o rio do mesmo nome, "de costa a costa", até sua confluência com o Paraná61. Desdobramento maior não houve, o Tratado de Navegação e Limites de 15 de julho de 1852, aliás, nem ratificado foi e a questão somente se reacendeu, em 1866, com a publicação do Tratado da Tríplice Aliança (Brasil, Argentina e Uruguai). Na ocasião, o Governo da Bolívia manifestou estranheza ante o fato de que as Potências Aliadas, ao decidirem sobre a expropriação do território do Estado paraguaio, incluíssem na retalhadura "gran porción del território boliviano", à Argentina destinando extensa região ocidental do rio Paraguai (Gran Chaco) e ao Brasil, na sua margem direita, o trecho compreendido entre a Bahia Negra e o Jaurú ${ }^{62}$. Os três Aliados trataram então de ressalvar, através de cartas e notas reversais, os direitos da Bolívia, cujo apoio o Ministro das Relações Exteriores do Paraguai, José Berges, solicitara, acenando-lhe com a oportunidade de "recuperar seus territórios e direitos usurpados pelo Brasil”63 . O General Mariano Melgarejo, que governava, naquela época, o país, inclinou-se, a princípio, a atender ao apelo e ofereceu ao Marechal Francisco Solano López uma “coluna de 12.000 bolivianos”64 . A ação diplomática do Brasil, enviando a Sucre, como Ministro Plenipotenciário, o Conselheiro Felipe Lopes Neto, neutralizou-o e levou-o a firmar o Tratado de 27 de março de 1867, pelo qual a Bolívia perdeu a margem direita do rio Paraguai e larga faixa de terra entre a foz do Beni e o Javari65 ${ }^{65}$ embora não o impedisse de permitir, sem obstáculos, a constante passagem de armamentos para o Marechal Francisco Solano López ${ }^{66}$.

A disputa em torno do Chaco, no entanto, agravou-se depois de terminada a guerra contra o Paraguai. A Argentina, escorada no Tratado da Tríplice Aliança, reclamou a posse de toda a margem esquerda do rio Paraná até o Iguaçú, e de toda a riba ocidental do rio Paraguai, até a Bahia Negra, em frente ao Fortim Coimbra, i. e., todo o território do Chaco, havendo suas tropas ocupado já a Villa Occidental. Como ao Brasil não convinha que ela ainda mais seu território dilatasse, o Governo Imperial não lhe reconheceu a pretensão, a pretexto de resguardar os direitos da Bolívia, e só admitiu o alargamento de sua fronteira, à margem ocidental do rio Paraguai, até o Pilcomayo. O Governo de Buenos Aires, com Domingo Sarmiento na Presidência da República e Carlos Tejedor no Ministério das Relações Exteriores, declarou então todo o Chaco província da Argentina, tendo Villa Ocidental como sua capital, e passou a exigir que as tropas brasileiras se retirassem de Assunção. O Governo Imperial, com os conservadores à frente e o Visconde de 
Rio Branco, José Maria da Silva Paranhos, na Presidência do Conselho de Ministros, reagiu, por outro lado, endurecendo sua posição, e assinou a paz em separado com o Paraguai, com o que rompeu, virtualmente, o Tratado da Tríplice Aliança. O conflito armado só não irrompeu porque, naquelas circunstâncias, nem o Brasil nem a Argentina estavam em condições de arcar com seus custos, ainda mais sem os recursos da Grã-Bretanha, cujos vastos e crescentes interesses, na região do Prata, sérios danos, certamente, sofreriam. Assim, o General Bartolomé Mitre, com as credenciais de Plenipotenciário, viajou então ao Rio de Janeiro, em 1872, e restaurou o clima favorável ao prosseguimento das negociações. Posteriormente, em 1875, o próprio Carlos Tejedor, como Plenipotenciário do Governo de Nicolás Avellaneda, continuou o trabalho e, através de sigilosa combinação com o representante do Paraguai, Jaime Sosa, procurou manter a Villa Occidental sob a soberania da Argentina, em troca do perdão da dívida de guerra. Mas a diplomacia do Brasil, informada sobre o acordo, atuou rapidamente e, a manipular o Governo do Paraguai, forçou a rejeição dos tratados de paz e de limites, que Tejedor e Sosa firmado haviam. O entendimento só alcançado foi, em 1876, quando Bernardo de Irigoyen, substituto de Tejedor, aquiesceu em fixar, no rio Pilcomayo, a linha de fronteira da Argentina, submetendo a questão de Villa Occidental à arbitragem do Presidente dos Estados Unidos, Rutherford Hayes. A decisão, anunciada em 1878, favoreceu o Paraguai e Villa Ocidental, com a retirada da Argentina, passou a chamar-se Villa Hayes. O Brasil obteve, assim, um triunfo, ao conseguir demarcar, conforme suas conveniências geopolíticas, as fronteiras do Paraguai com a Argentina, que incorporou o Chaco Austral, ao sul do rio Bermejo, e o Chaco Central, situado entre o Bermejo e o rio Pilcomayo, mas não pode assenhorear-se, igualmente, do Chaco Boreal ou Gran Chaco, com cerca de 297.938 km², o equivalente a três quintas partes do território total do Paraguai.

A Bolívia, que, embora pedisse, nem ouvida fora pelos Aliados ${ }^{67}$, não tivera, até então, nem condições nem meios de forças a consideração de seus reclamos, confusa e inconseqüentemente formulados. Durante a Guerra da Tríplice Aliança nem sequer protestara quando os exércitos, quer do Marechal Francisco Solano Lopez quer dos Aliados, atravessaram o rio Paraguai e, alcançando sua margem direita, penetraram o Chaco. A partir de 1878, porém, a Bolívia, com a economia estagnada devido ao esgotamento das minas de prata, abismou-se em uma seqüência de graves problemas como a seca, a fome, a peste e outros, decorrentes do fortíssimo terremoto, que nos fins de 1877 devastara seus portos na costa do Pacífico (Tocopilla, Antofagasta, Cobija), localizados entre Taltal, ao norte do Chile, e Arica, no sul do Peru ${ }^{68}$. A derrota na Guerra do Pacífico (18791883), travada, juntamente com o Peru, contra o Chile, engravesceu-lhe mais ainda a situação, ao transformá-la em um país mediterrâneo e, o que mais asfixiante se afigurava, sem sequer uma saída para a Bacia do Prata. Em realidade, a Bolívia não tanto se beneficiara com o boom dos nitratos, quando entre 1866 e 1879 
explorava juntamente com o Chile as jazidas de salitre, e os portos de Tocopilla, Antofagasta e Cobija, perdidos durante a Guerra do Pacífico, pouco lhe serviram, dado que ela não dispunha de grandes excedentes para exportação. Mas o fato foi que seu interesse no Chaco e em obter uma saída para o rio Paraguai recresceu, a partir de 1879, depois do laudo arbitral do Presidente Hayes e coincidentemente com a ocupação da costa do Pacífico pelo Chile. Naquele ano, o Presidente Narciso Campero, em carta ao Imperador Pedro II, pleiteou a devolução das margens do Alto Paraguai, cedidas ao Brasil por Melgarejo, sob o argumento de que o Tratado de 1867 contrariava os “claros desígnios de la Providencia”, ao impedir que a população da Bolívia acesso ao rio tivesse e a privar, assim, de "un órgano respiratorio que le ha concedido la voluntad del Supremo Hacedor"69 . Ao mesmo tempo, ele determinou que Antônio Quijarro, seu Ministro em Buenos Aires, viajasse para Assunção, como Plenipotenciário, a fim de negociar um acordo que garantisse à Bolívia o domínio sobre a margem direita do Paraguai, ao sul da Bahia Negra. Quijarro e José Segundo Decoud, Ministro das Relações Exteriores do Paraguai, em 15 de outubro de 1879, firmaram então um Tratado, pelo qual transferia para a Bolívia mais da metade do Chaco. O Tratado Quijarro-Decoud aprovado não foi pelo Paraguai, da mesma forma que dois outros mais - Tamayo-Aceval (1887) e Ichazo-Benitez (1894) $)^{70}$ - celebrados até o final do século XIX ${ }^{71}$.

Como os dois países nenhum entendimento alcançassem e a construção pela Bolívia, no Chaco, dos fortins Ballivian e Guachalla quase uma guerra desencadeasse, a Argentina, sob o governo de José Figueroa Alcorta e tendo Estanislao S. Zeballo como Ministro das Relações Exteriores, ofereceu os bons ofícios em busca de uma solução amigável para o litígio. Em 12 de janeiro de 1907, os Plenipotenciários da Bolívia, Cláudio Pinilla, e do Paraguai, Adolfo R. Soler, firmaram então um Protocolo, em que as partes contratantes se comprometiam a não minorar nem avançar no Chaco as possessões existentes até aquela data e entregavam a questão à arbitragem do Presidente da Argentina. O entendimento, contudo, não evoluiu, por vários motivos, entre os quais, principalmente, a renúncia do Presidente Figueroa Alcorta, em virtude de grave incidente diplomático com a Bolívia, que julgava o Protocolo atentatório à sua soberania. Confiança, naturalmente, não havia na isenção da Argentina. Segundo se informara, o próprio Chanceler Estanislao S. Zeballos era grande concessionário de terras no Chaco, as quais adjudicadas the foram pelo Governo do Paraguai ${ }^{72}$. E na Argentina havia quem alimentasse a esperança de que ela talvez ainda aquela região incorporar pudesse, o que a salvaria de muitos problemas, no futuro, e lhe asseguraria a jurisdição sobre o rio Paraguai, a contrabalançar a expansão do Brasil em Mato Grosso. "Los Estados Unidos llevan su jurisdicción alli donde existen intereses de su nacionalidad" - assim um documento encaminhado ao Chanceler Victorino de la Plaza, por volta de 1810, argumentava em favor da "reincorporação" do Chaco pela Argentina, acentuando que 
“El mal llamado Chaco Paraguaio solo ha sido poblado por capitales argentinos, espoliados por los políticos de Asunción, y basta mirar el mapa para ver que él forma continuación al norte del território argentino, sin solucción de continuidad al norte del Pilcomayo". ${ }^{73}$

De acordo com o mesmo documento, desde que "los dueños" e los “centros de población” no Chaco eram argentinos, seu território à Argentina devia ser incorporado, para o que bastava, a aproveitar que uma revolta dos marinheiros debilitara a Armada brasileira (1910), estacionar navios de guerra em frente a Villa Hayes, Concepción e Puerto Casado ${ }^{74}$.

O Chanceler, depois Presidente (1914-1916), Victorino de la Plaza, evidentemente não acolheu semelhante sugestão. Mas fato era que, enquanto a Bolívia se emaranhava em controvérsias jurídicas e diplomáticas, a defender, para respaldar seus reclamos, o uti possidetis juris, rechaçado pelo Paraguai, pois o aditivo juris contradizia o princípio do uti possidetis, que, na linha do direito romano, só podia configurar-se de fato, a Argentina, na realidade, ocupara economicamente o Chaco $^{75}$, embora os EUA também ali investido houvessem, até 1918, um montante superior a US\$ 1 milhão ${ }^{76}$. Argentinas eram, na sua grande maioria, as estâncias para a criação de gado e as empresas dedicadas à venda de terras e à produção de tanino. Elas operaram grandes somas de capital, empregaram cerca de 20.000 trabalhadores, possuíam mais de $200 \mathrm{~km}$ de vias férreas para o transporte do quebracho, dispunham de numerosos portos à margem do Rio Paraguai e os navios de cabotagem argentinos, na maior parte pertencentes à Companhia Mihanovich, monopolizavam o trânsito fluvial ${ }^{77}$. A produção mensal de tanino das quatro empresas argentinas e uma norte-americana chegara a 8.000 toneladas, no início dos anos trinta. E ela se assentava sobre vastas propriedades de terra. Conforme o jornalista Lindolfo Collor assinalou, em nenhuma parte, dentro do sistema econômico capitalista, uma propriedade existira com 300 léguas quadradas. Somente no $\mathrm{Chaco}^{78}$. E ela pertencera à empresa argentina Casado \& Cia., cujo domínio chegara a estender-se por cerca de 3.000 a 4.000 léguas quadradas ou, segundo outra medida, por mais de 4 milhões de hectares ${ }^{79}$, sendo posteriormente reduzida com a divisão em lotes coloniais, para venda às famílias menonitas, canadenses ou russas. Na avaliação do Itamaraty, para essa como para as demais empresas argentinas, o domínio sobre o território do Chaco constituía "questão de maior relevância, em virtude da diferença entre as grandes facilidades por elas ali obtidas e aquelas mais restritas, que a Bolívia lhes propiciava" ${ }^{80}$. Por este motivo, quando o conflito armado entre os dois países irrompeu, o Governo de Buenos Aires não lhes podia deixar de refletir os interesses, respaldando o Paraguai, sobretudo depois que o General Agustin P. Justo, cunhado de Carlos Casado, assumira a Presidência da Argentina (1932-1938) e nomeara seu Ministro das Relações Exteriores, o antigo advogado daquela empresa proprietária de vasta extensão de terras no Chaco, Carlos Saavedra Lamas ${ }^{81}$. 
Fatores vários e complexos entrançaram-se e concorreram, naturalmente, para a eclosão da Guerra do Chaco. A região - o Chaco Boreal ou Gran Chacorevestia-se de fundamental importância para a economia do Paraguai. Um terço da renda nacional proveio, em 1932, de seu solo, onde metade do rebanho bovino existente no país se encontrava e por onde grande parte do total de suas linhas férreas se estendia, para o transporte do quebracho até os portos de Pinasco, Casado, Sastre, Palma Chica, Puerto Maria, Guarany e Mihanovich. Com a perda do Chaco Boreal o Paraguai ficaria reduzido a uma insignificante mesopotâmia, com pouco menos de $160.000 \mathrm{~km}^{282}$. Muito diferente a situação que configurava para a Bolívia, que apenas alegava a condição de sucessora da Audiência de Charcas para reivindicá-lo. O Chaco não se integrava no sistema produtivo do país, bem distante estava dos seus centros econômicos e políticos, localizados no Altiplano, onde as populações se concentravam, e lá a presença da Bolívia somente se podia perceber, através de pequenas guarnições militares, algumas das quais sediadas à margem do Pilcomayo, com menos de 350 soldados, para uma população de menos de 5.000 habitantes. Na longínqua região de Chiquitos, com cerca de 10.000 habitantes, menos de 250 soldados compunham a guarnição ${ }^{83}$. Para Bolívia, como país mediterrâneo, o valor do Chaco consistia no fato de que, cortado pelo rio Paraguai e seus afluentes, permitiria que ela alcançasse uma saída entre a Bahia Negra e o Pilcomayo, fundamentalmente para o Departamento de Santa Cruz de la Sierra, embora seu comércio de importação e exportação não chegasse a $£ 200.000$ anuais. E o que mais importava, no caso, era que a Standard Oil começara a exploração do petróleo, mas o transporte para os portos do Pacífico afigurava-se difícil e custoso, devido aos aclives dos Andes. Seu escoamento, portanto, dependia de que a Bolívia obtivesse acesso ao Atlântico, através da Bacia do Prata.

Embora a descoberta de jazidas de petróleo, na Bolívia, ocorresse antes do século XX e muitos empresários recebessem concessões para explorá-lo, a operação dos primeiros poços, na bacia do Bermejo, só realmente começou por volta da 1925, depois que a Standard Oil of New Jersey comprara as áreas adjuntas aos empresários norte-americanos Richmond Levering, de New York (1 milhão de hectares) e de William e Spruille Braden (2 milhões de hectáres) ${ }^{84}$. A produção, que fora de $424 \mathrm{~m}^{3}$ em 1925, subira para $4.386 \mathrm{~m}^{3}$, em 1929, quando então os poços de Camiri e Sanandita em funcionamento já estavam, com a extração, respectivamente, de $942 \mathrm{~m}^{3}$ e $2.690 \mathrm{~m}^{3}$ de óleo $^{85}$. A Standard Oil, até aquela data encontrara petróleo em 9 poços dos 21 perfurados e a Bolívia solicitou à Argentina autorização para construir em seu território, dois oleodutos, um dos quais desde Mirtle, à margem do Bermejo, até a estação ferroviária de Embarcación, e o outro, o principal, partindo da Yacuiba até o porto de Formosa, Santa Fé ou Campana, sobre o rio Paraná ${ }^{86}$. O Presidente Hipólito Yrigoyen não a concedeu e suspeita houve de que tal negativa se deveu à influência da Royal Dutch-Shell e dos interesses 
britânicos, prevalecentes em Buenos Aires. Entretanto, o que efetivamente a determinou, segundo estabelecer se pode, foi a política, que o General Enrique Mosconi, Presidente da Yacimentos Petrolíferos Fiscales (YPF), tratava de desenvolver, visando à completa nacionalização do petróleo na Argentina ${ }^{87}$. A atitude da Argentina, por conseguinte, não deixara à Bolívia como alternativa tentar obter, pelas armas, uma saída através do Chaco, no rio Paraguai, sobretudo quando o Presidente Daniel Salamanca e as autoridades militares imaginaram que ela possuía imensas reservas de petróleo, capazes de abastecer o mundo e de fazê-la superar seu atraso econômico. Na verdade, as pesquisas pareciam assegurar a existência de extensos lençóis de petróleo junto ao lago Titicaca, em grande parte do Departamento de Cochabamba e, sobretudo, em uma curva, que desde os limites com o Peru aos $13^{\circ}$ de latitude, seguia do Oeste ao Leste, desviando-se para o Sul até alcançar o meridiano 63, onde a formar um ângulo, tomava a direção Norte-Sul e atravessava a fronteira da Argentina ${ }^{88}$.

A leste do meridiano 63, uma zona disputada do Chaco Boreal, nada indicava, conquanto improvável não fosse, a existência de petróleo, como no Paraguai se imaginava. A Standard Oil sabia que diminuto era, se realmente havia, o fundamento para tal esperança e considerava mesmo "improvável” encontrá-lo em qualquer quantidade comercial a leste da linha dos hitos (marcos), onde ela só possuía as concessões conhecidas como $\mathrm{N}^{\circ}$ s. 10, 11, 12, 118, Lagonillas, e os trabalhos foram abandonados ou materialmente reduzidos ${ }^{89}$. Cerca de 21 poços, perfurados dentro do território da Bolívia, próximos à linha de separação da área litigiosa, não produziam mais que $1.000 \mathrm{~b} / \mathrm{d}$ e estavam tão espalhados que se tornava antieconômico os reunir em uma única localidade. A Standard Oil, de acordo com as informações prestadas pelo seu representante na Argentina, Robert Wells, a Spruille Braden, Chefe da Delegação dos EUA à Conferência de Paz em Buenos Aires, investira muitos capitais nas suas explorações, ao sudoeste da Bolívia; mas a única a apresentar rendimentos era a localizada na zona do Bermejo, onde a produção alcançava $2.000 \mathrm{~b} / \mathrm{d}^{90}$. Por isto, diante de resultados tão insatisfatórios, as instruções, emitidas desde 1931, foram no sentido de cessar as perfurações, realizando-se a última em 1932. Assim, com uma produção de apenas 3.000 b/d, lucrativa não se afigurava a construção de pipe lines para levar o petróleo até o rio Paraguai ou mais ao sul, através da Argentina, aos mercados de Santa Fé, Rosario e Buenos Aires ${ }^{91}$. O problema do petróleo, como fator que, em 1932, contribuiu para desencadeamento das hostilidades, merecia, no entanto, atenção, pois o Presidente Daniel Salamanca não confiava nos dados da Standard Oil, supunha que mais petróleo havia do que ela informava, e considerava que no caso das jazidas existentes, quer no Chaco quer ao longo do meridiano 63, dentro do território da Bolívia propriamente dita, as estações terminais dos oleodutos situadas deveriam ser à margem direita do rio Paraguai. O próprio Presidente Ausebio Ayala, já em 1928, propusera liquidar a questão do Chaco por meio de concessão à Bolívia de 
um corredor de saída com um porto em Villa Hayes, sobre o rio Paraguai ${ }^{92}$. Conforme o Embaixador José Joaquim de Lima e Silva Moniz de Aragão, então Secretário Geral do Itamaraty, salientou, necessário cumpria reconhecer que aos bolivianos não eram territórios despovoados que faltavam. Desde que perderam os portos do Pacífico, sua "idéia fixa” era sair da angustiosa situação, em que se achavam, de povo mediterrâneo, em meio de desertos. Saída ao mar, tal era a "preocupação constante, característica da Bolívia" - Moniz de Aragão acrescentou, mostrando que, com o que gastava na guerra ela podia custear a adequada ligação do Altiplano à Bahia de Cáceres e talvez as próprias obras de que Puerto Suares carecia para o seu desejável aproveitamento ${ }^{93}$. Mas o diplomata brasileiro Orlando Leite Ribeiro, servindo em Buenos Aires, informou ao General Pedro Aurélio de Goes Monteiro, Chefe do Estado-Maior do Exército brasileiro, que a Argentina via “com pavor” a saída da Bolívia pelo rio Paraguai, dado que inundaria o mercado com petróleo, "matando sua recente indústria de Comodoro Rivadavia"94. A observar que o "vasto lençol do subsolo petrolífero do Chaco" se estendia mais para o lado da Bolívia e o que nas proximidades do rio Paraguai existia já era argentino, ele acentuou que

"A questão do petróleo é o que mais interessa à Argentina e daí o fato de que ela não tenha nunca apoiado a pretensão justa da Bolívia em obter uma saída ao rio". 95

Um documento interno do Exército brasileiro, encaminhado ao Conselho Superior de Guerra pelo General Waldomiro Castilho de Lima, Chefe da Inspetoria do $1^{\circ}$. Grupo de Regiões militares, apoiou-se, aparentemente, nas informações transmitidas por Orlando Leite Ribeiro ao General Goes Monteiro e concluiu também que a questão do petróleo existente no Chaco, cujos lençóis se encontravam na Cordilheira Charaguá, preocupava seriamente a Argentina, que aí percebia uma concorrência comercial, capaz de destruir a produção de Comodoro Rivadavia ${ }^{96}$.

A descoberta das jazidas de petróleo, em Comodoro Rivadavia, Província de Chubut, na Patagônia, ocorrera em 1907 e o então Presidente da Argentina, José Figueroa Alcorta, transformou a área, de acordo com a Lei de Terras República de 1903, em reserva nacional, na qual proibiu concessões privadas, ao longo de 200.000 ha., i. e., 25 km em todas as direções. Em 1909, ele decidiu dar cauteloso apoio à emergente indústria do petróleo, ao solicitar ao Congresso a aprovação de recursos, da ordem de 200.000 pesos, por modo que o Estado assumir pudesse a sua produção, porém o Senado, com a Lei 7059, de 1910, reduziu a reserva a 5.000 ha. em torno de Comodoro Rivadavia ${ }^{97}$. Abertos então foram aos investimentos 195.000 ha. da reserva de 1907 e o grande número de concessões requeridas, cerca de 109, a abrangerem Neuquén, Chubut e Santa Cruz - três dos cinco territórios que formavam a Patagônia - mostrou a necessidade de impedir que a Standard Oil e outras companhias estrangeiras se apossassem das melhores áreas. O Presidente Roque Sáenz Peña (1910-1914), ao suceder Figueroa Alcorta, adotou 
uma política ainda mais rígida. Anulou as concessões pelas companhias particulares obtidas e ainda não exploradas, alargou as reservas do Estado para 160.000 ha. em Chubut, bem como criou a primeira companhia estatal de petróleo do mundo, a Dirección General de Explotación de Petroleo de Comodoro Rivadavia, cuja produção, entre 1916 e 1919, cresceu cerca de $45 \%$, a alcançar $188.111 \mathrm{~m}^{398}$. Essa companhia, ao final do Governo do Presidente Hipólito Yrigoyen (1916-1922), reorganizada foi (1922), sob o nome de Yacimientos Petrolíferos Fiscales (YPF), e sua direção entregue ao General Enrique Mosconi, possibilitando-lhe promover "una de las más profundas campañas nacionalistas que ha visto la Argentina"99, com o objetivo de "argentinizar", na medida do possível, tanto a produção quanto a distribuição de petróleo e paralisar a penetração da Standard Oil no norte do país ${ }^{100}$. Com efeito, a Standard Oil, que dominava, através da West India Oil Company (WICO), cerca de $80 \%$ do comércio nacional de gasolina e desfrutara, em Buenos Aires, do monopólio absoluto do mercado ${ }^{101}$, começara a adquirir, naquela época, i. e., entre 1922 e 1923, concessões nas Províncias de Salta e Jujuy, onde, por volta de 1870, explorações particulares esporadicamente se realizaram, sem maior êxito $^{102}$. Mosconi manifestava a seu respeito opinião bastante negativa. Julgava que os norte-americanos, como "novos ricos”, não reconheciam limitações, para a consecução dos seus propósitos, e suas reações chegavam até “el desconocimiento y atropello de la soberania de otros pueblos"103. E procurou, conseqüentemente, contrapor-se à expansão da Standard Oil. Esta posição contou com o apoio do Presidente Marcelo T. Alves (1923-1928), que, também eleito pelo Partido Radical, fortaleceu os planos de Mosconi, mediante a implementação de política ainda mais agressivamente nacionalista, visando a consolidar e expandir a Yacimientos Petrolíferos Fiscales. Esta companhia estatal, por volta de 1929, já respondia por 234 milhões de litros de gasolina, contra 126 milhões produzidos pelas corporações estrangeiras, dos 700 milhões consumidos na Argentina, já a emergir como um grande mercado em expansão superando a própria França, devido às suas importações de automóveis, que a colocaram na liderança absoluta do ranking mundial, com mais do que o dobro do Brasil, então no segundo lugar ${ }^{104}$. Não foi, por conseguinte, devido à influência da Royal Dutch Shell e sim para defender a prevalência da YPF, enquanto empreendimento do Estado que, no seu segundo mandato, o Presidente Hipólito Yrigoyen (1929-1930) não permitiu à Bolívia construir, com financiamento da Standard Oil, os dois oleodutos, que seu território atravessariam, até Formosa, Rosário ou Zárate (Buenos Aires), sobre o rio Paraná.

Àquele tempo, a Standard Oil of New Jersey e a Royal Dutch Shell disputavam o petróleo na Argentina, como no resto da América do Sul, interessadas, em larga medida, em assenhorear-se de reservas para o futuro. O espectro da Standard Oil, contudo, era o que mais assustava. Em face de problemas internos nos EUA, da explosão do nacionalismo no México e da difícil competição com os interesses britânicos no Oriente Médio, elas e outras companhias norte-americanas 
voltaram as atenções para a América do Sul, onde, durante os anos 20, seus investimentos saltaram de US\$ 67 milhões para US\$ 476 milhões ${ }^{105}$. A participação da América do Sul no total dos investimentos dos EUA na exploração do petróleo aumentou de 17\%, em 1919, para 34\%, em $1929^{106}$, havendo a Standard Oil adquirido concessões na Colômbia, Venezuela, Peru, Brasil, Bolívia e Argentina. A Royal Dutch Shell, cuja subsidiária, a Anglo-Mexican Petroleum Production Co. já estava a reduzir, no México, suas operações só obteve maior sucesso na Venezuela, ao descobrir (1922), em torno do lago Maracaibo, grandes reservas de petróleo, que transformaram aquele país, com uma produção de 139 milhões de barris em 1929, no maior produtor mundial, superado apenas pelos EUA ${ }^{107}$ Inevitável se tornava, portanto, que, naquelas circunstâncias, os tentáculos da Standard Oil of New Jersey, principalmente, ou da Royal Dutch Shell percebidos fossem, com ou sem real fundamento, por trás de vários acontecimentos políticos, a removerem obstáculos à satisfação dos seus interesses.

Indícios houve - e fortes - de que aquelas companhias concorreram, direta ou indiretamente, para que o General José F. Uriburu, em 6 de setembro de 1930, desfechasse um golpe de Estado, derrubando o Governo do Presidente Hipólito Yrigoyen, que se dispunha a nacionalizar toda a produção de petróleo na Argentina e firmara um contrato com a firma soviética Iuyamtorg, para a compra de gasolina por preço abaixo da cotação no mercado mundial ${ }^{108}$. De qualquer modo, não restou a menor dúvida de que ele recebeu o apoio dos governadores de Salta, Joaquin Corvalán, e de Jujuy, Benjamín Villafañe, bem como de outras Províncias do interior, contrários à estatização do petróleo, por temerem a ascendência de Buenos Aires através da YPF, e interessados em fazer maiores concessões à Standard Oil, na esperança de que ela pudesse promover o progresso da região. A antiga contradição, ainda latente, entre os interesses do Estado unitário argentino, representados pela consolidação da YPF e pela política de crescente estatização do petróleo, e as tendências federalistas das Províncias, empenhadas em manter a sua autonomia e conservar o controle das concessões, uma vez mais aflorou e contribuiu para a derrocada do regime constitucional. E, como o cientista político francês Alain Rouquié observou, o problema do petróleo constituiu um dos aspectos do conflito entre Yrigoyen e a oligarquia, encontrando-se os "interesses petrolíferos amplamente representados” entre os conspiradores e no seio do Governo provisório $^{109}$. O historiador norte-americano Carl E. Solberg também constatou que muitos dos ministros de Uriburu serviam às companhias estrangeiras como consultores jurídicos e admitiu que bem podia ser verdade que elas utilizaram o suborno ou outros meios para lançar os militares contra Yrigoyen ${ }^{110}$. De fato, o primeiro Ministro do Interior no Governo Uriburu (1930-1932) foi Matias Sanchez Sorondo, consultor jurídico da Standard Oil. O Ministro da Educação Pública, Ernesto Padilha, tinha vinculações com a WICO, subsidiária da Standard Oil, e vários outros, como Ernesto Bosh (Relações Exteriores), Octavio S. Pico (Obras Públicas) e 
Horácio Becas Varela (Agricultura) foram ou ainda eram empregados de companhias petrolíferas da Grã-Bretanha ${ }^{111}$.

No caso da Guerra do Chaco, a versão mais difundida e generalizada foi a de que a Standard Oil of New Jersey e a Royal Dutch Shell instrumentalizaram a Bolívia e o Paraguai, para que disputassem, pelas armas, a posse das jazidas de petróleo porventura existentes naquela região ${ }^{112}$. Em outras palavras, o que prevaleceu foi a percepção esquemática e simplista de que aquele conflito refletiu, sobretudo, a competição entre duas potências imperialistas, os EUA e a GrãBretanha, representadas, respectivamente, pela Standard Oil e Royal Dutch Shell. Efetivamente, conquanto os EUA exercessem forte influência no Paraguai, desde que a Conferência de Não-Agressão (1931) em Washington se realizara, muitas suspicácias se levantaram de que elas estariam a favorecer Bolívia, devido aos interesses e às atividades da WICO, subsidiária da Standard Oil, lá desenvolvidas $^{113}$. Evidente se afigurava que, caso a Bolívia conquistasse o Chaco e obtivesse um porto sobre o rio Paraguai, a Standard Oil beneficiada seria e esta constituía, indubitavelmente, a base da inimizade e da desconfiança contra os EUA, no Paraguai predominantes ${ }^{114}$. Segundo o diplomata britânico Tottenham-Smith, a opinião pública, no Paraguai, estava geralmente convencida de que a Standard Oil exercia pressão sobre o Governo dos EUA, a fim de obter fundos, armas e toda espécie de assistência para a Bolívia ${ }^{115}$. E o que mais contribuiu para solidificar tal convicção foi o discurso do Senador norte-americano, por Louisiania, Huye Pierce Long, pronunciado em 30 de maio de 1934 e no qual acusou a Standard Oil e outros interesses a ela associados de promover a guerra e prover fundos à Bolívia, com o propósito de arrebatar o Chaco ao Paraguai ${ }^{116}$. Estas alegações, entretanto, não se confirmaram. O próprio Embaixador Spruille Braden, representante dos EUA à Conferência da Paz em Buenos Aires, reconheceu que não obstante exageros ou prejuízos da Bolívia, a Standard Oil não manejara inteligentemente as relações com o seu governo, como alguns fatos evidenciaram ${ }^{117}$. Logo depois de iniciado o conflito, a Standard Oil começara a desmantelar uma de suas refinarias, a fim de removê-la para a Argentina, quando o Governo boliviano descobriu e a forçou a repor os equipamentos e recomeçar a refinação do petróleo. Em outro momento crítico, ela avisou o Governo boliviano que os poços cessado haviam de produzir e que não mais teria gasolina disponível. No entanto, tão pronto o Presidente Daniel Salamanca ameaçou nacionalizar seus campos e refinarias, a Standard Oil anunciou que a produção continuaria tão grande como sempre. Por fim, quando a Bolívia, a concentrar sua Força Aérea em Puerto Suarez para defendê-lo de um provável ataque do Paraguai, necessitou de gasolina de aviação, a Standard Oil só se dispôs a fornecer qualquer quota, mediante pagamento à vista, por um preço duas vezes mais alto do que o de qualquer outro competidor e, mesmo assim, entregue em Corumbá, no Brasil ${ }^{118}$. Aliás, a falta de suficiente gasolina foi permanente obstáculo à mobilidade do Exército boliviano, que muitas vezes teve 
de abastecer-se no Peru, conforme o historiador paraguaio Alfredo M. Seiferheld constatou, assinalando que "la Standard Oil no jugó límpio con Bolívia"119 . Na verdade, durante a guerra, ela fornecera combustível, em proporções e preços equivalentes, tanto à Bolívia quanto ao Paraguai ${ }^{120}$. E pior ainda, descobriu-se, posteriormente, que também ocultara do Governo de la Paz a exploração de vários poços, a fim de sonegar impostos, bem como evitar o pagamento de royalties, e desde 1925 - 1926 até 1935, bombeara, através de um oleoduto clandestino, que cruzava o rio Bermejo, cerca de 9,1 milhões de barris de petróleo para a Argentina $^{121}$. Seu comportamento foi tão contrário e hostil aos interesses da Bolívia que nem o Embaixador Spruille Braden, representante dos EUA na Conferência de Paz de Buenos Aires ${ }^{122}$, pode deixar de criticá-la, em algumas oportunidades, inclusive em ofícios do Departamento de Estado ${ }^{123}$. E a opinião pública, naquele país, voltou-se tão fortemente contra ela que tornou inevitável e irreversível o confisco de suas propriedades, como fez o Coronel David Toro, após derrubar o Presidente José Luis Tejada Sorzano (1935-1936) e assumir o poder, em 1937. Entretanto, não só por causa do seu procedimento, provável não foi que a Standard Oil levado houvesse a Bolívia a uma guerra difícil, comprometendo vultosos capitais, quer para conquistar uma saída para a Bacia do Prata quer com a esperança de encontrar petróleo no Chaco paraguaio, onde ela já sabia não existir em quantidade comercial, conforme os conhecimentos geológicos da época, sem antes esgotar todos os recursos políticos em Assunção.

Quanto à Royal Deutch Shell, nada se soube que comprovasse ou, ao menos, indicasse qualquer influência sua quer sobre a eclosão quer sobre o desenvolvimento do conflito no Chaco. A acusação, amplamente difundida pela esquerda, de que ela, a disputar com a Standard Oil as jazidas de petróleo porventura existentes no Chaco Boreal, devem-se, sobretudo, à posição assumida pela Argentina, onde os interesses da Grã-Bretanha predominavam ${ }^{124}$. Esta circunstância, entretanto, não autorizava, de fato, semelhante conjectura. Interesses da Grã-Bretanha também havia na Bolívia, à qual a companhia Vicker Armstrong vendera armamentos e, em 1933, solicitou a interferência do Foreign Office junto ao Governo do Chile, no sentido de que permitisse a passagem de um carregamento, no valor de $£ 300.000$, pelo porto de Arica ${ }^{125}$. A Grã-Bretanha, na verdade, exportara grandes quantidades de armas, munições e outros petrechos de guerra, inclusive aeroplanos, tanto para a Bolívia quanto para o Paraguai, entre 1932 e $1935^{126}$. De modo geral, as indústrias de material bélico não só da Grã-Bretanha e dos EUA como também da Alemanha, França, Bélgica, Tchecoslovaquia, Espanha e Suíça realizaram com aqueles dois países beligerantes vultosos negócios, financiados por grandes bancos europeus e norte-americanos, entre os quais o Midland Bank, o Banque de Paris et Pays-Bas e o Chemical Bank and Trust Co. ${ }^{127}$ Sem dúvida, interesse elas tiveram na deflagração da Guerra do Chaco, a primeira a empregar, de forma exclusiva, a tração mecânica, a utilizar amplamente 
o aeroplano e a demonstrar o valor da pistola-metralhadora ${ }^{128}$. E a Alemanha, entre as grandes potências, foi a que melhor aproveitou suas lições, ao avaliar a importância do reconhecimento aéreo, da surpresa, das manobras de limpeza, do uso maciço dos tanques, da infantaria motorizada, das unidades técnicas e do conceito de nação em armas ${ }^{129}$. O Marechal Erwin Rommel teve como precursor o General José Felix Estigarríbia, que, com o retorno à manobra genuína na guerra, teve como objetivo tomar Charaguá, seguir por Lagunillas até Monteagudo, invadir o Departamento de Santa Cruz de la Sierra e, finalmente, alcançar Camiri, capturando a refinaria de petróleo, responsável pelo suprimento do combustível à Bolívia ${ }^{130}$. $\mathrm{E}$, aí, o curso da guerra mudou. Conforme o diplomata brasileiro Joaquim Palmeiro salientou, quando o Presidente Eusébio Ayala e o Comandante-em-Chefe José Estigarríbia consideraram pela primeira vez a possibilidade de conquistar os campos de petróleo da Standard Oil, a Liga das Nações suspendeu o embargo de armas à Bolívia, o soldado boliviano subitamente se tornou imbatível e o exército paraguaio sofreu os primeiros reveses depois de dois anos de luta ${ }^{131}$. As tropas do Paraguai pararam.

A questão do petróleo, evidentemente, assumiu fundamental importância, como fator da Guerra do Chaco, porém mais ao nível do imaginário político do que da realidade econômica. O Presidente Daniel Salamanca, ao decidir "pisar forte" no Chaco, presumia que a Bolívia dispunha de reservas de petróleo, suficientes para abastecer o mundo e arrancá-la do subdesenvolvimento, e só necessitava do acesso ao Oceano Atlântico, através do rio Paraguai e do estuário do Prata. O Presidente Eusébio Ayala, do Paraguai, supunha, igualmente, que a Bolívia possuía 8 milhões de hectares, "de los más ricos terrenos petrolíferos”, onde a "inmensidad de la riqueza del subsuelo" faria "de la zona uno de los más grandes centros de producción del mundo" 132 . Sua esperança era conquistar esta zona, o que possibilitaria ao Paraguai ressarcir-se dos custos da guerra, segundo ele próprio confessou, a afirmar que

"Nuestra frontera natural e histórica llega al Parapeti, cordillera Chiriguanos y Pilcomayo. Si la victoria no nos asegura esta frontera, se originará un hondo malestar en el país (...) La posesión de la zona del petróleo nos servirá además para recuperar nuestras pérdidas y levantar el país de la prostración en que habia de quedar" 133 .

Esta crença, a de que o sub-solo da Bolívia, na região do rio Parapeti, lindeira do Chaco Boreal, e adjacências, escondia imensos depósitos de petróleo, influenciou também os dirigentes da Argentina e concorreu para que ela respaldasse o Paraguai, sob o disfarce do que denominou de neutralidade benévola. Este comportamento, durante o conflito e no curso da Conferência de Paz realizada em Buenos Aires (1935-1938), não obedeceu, certamente, às prováveis ambições da Royal Deutch Shell, apesar de que com elas pudesse coincidir, e sim aos reais interesses da YPF, já a responder por 37,5\% (835.565 m³) da produção nacional 
contra uma participação de 62,5\% (1,4 milhão de m³), das companhias particulares, entre as quais a Standard Oil of New Jersey como sua principal concorrente aparecia $^{134}$. Ao que tudo indicava, os militares nacionalistas, que, não obstante a queda do General Mosconi, ainda influíam no Governo de Buenos Aires, temiam que a Standard Oil, com a posse de enormes reservas na Bolívia, segundo imaginavam, alcançasse a saída para o estuário do Prata, através do rio Paraguai, e terminasse por esmagar a YPF, ao ponto de excluí-la até mesmo da exploração das jazidas existentes em Salta, Jujuy, Mendoza e em outras Províncias da própria Argentina. Por esta razão, o Governo do General Agustín P. Justo, embora tratasse de assegurar os investimentos britânicos e se opusesse ao monopólio estatal do petróleo, resistiu, tanto quanto pode, à demanda de concessões da Standard Oil, escorada por poderosos políticos de Salta, como Robustiano Patrón Costas, que se tornara um dos árbitros do regime ${ }^{135}$. Naquelas condições, portanto, à Argentina absolutamente não convinha a vitória da Bolívia, pois desviaria do seu território as atividades relacionadas com a indústria do petróleo, se ela a conquistar viesse um litoral apropriado. Por outro lado, em face da completa dependência e subordinação da economia do Paraguai à Argentina ${ }^{136}$, reforçada por toda a espécie de cooperação durante a guerra, inevitável tornar-se-ia a concentração de acordos, mediante os quais toda a produção de petróleo da região de Parapeti, na Bolívia, e a que ocorrer viesse no Chaco Boreal cairia em poder da YPF. Não sem razão todos perceberam, como o Coronel Francisco Barrero V., que o "objetivo estratégico” da Argentina e do Paraguai só podia ser a destruição da máquina militar da Bolívia, tendo por “meta econômica” o Chaco e o petróleo ${ }^{137}$. E, se esta questão já se tornara, durante a guerra, cada vez mais importante, ela assumiu uma significação ainda maior, como fator de negociação diplomática, após a instalação da Conferência de Paz em Buenos Aires, com a cessação das hostilidades, em junho de 1935.

A crença de que o petróleo existia, em quantidade comercial, a leste da linha de hitos, no Chaco Boreal, continuou a orientar a resistência tanto de Bolívia quanto do Paraguai à conclusão de um acordo, não obstante as informações prestadas pela Standard Oil e transmitidas pelo Embaixador norte-americano Spruille Braden, sobre os resultados negativos de suas pesquisas ${ }^{138}$. Ainda em 1937, o Paraguai conseguiu interessar o Governo francês, que encaminhou a questão à Compagnie Française de Petrole, que, obtendo a cooperação financeira do Banque Lazare e do Banque de Paris e des Pays-Bas, organizou uma pequena missão com o objetivo de pesquisar não somente petróleo, mas também outras fontes de recursos econômicos naquele país ${ }^{139}$. A Bolívia protestou, a alegar que as explorações se realizariam dentro da região do Chaco boliviano, mais próxima à linha intermediária do setor ocidental e, por conseguinte, dentro da área de separação, que os exércitos assinalaram $^{140}$. E, como a opção dada à companhia francesa fora por seis meses, o Embaixador Spruille Braden desconfiou que o Paraguai estava a deixar que o 
prazo decorresse, pois sua intransigência e teimosia em manter a ocupação militar da linha ocidental decorriam não da instabilidade política interna e sim da convicção de que grande riqueza de petróleo ali existia ${ }^{141}$. Perigo havia de que a guerra se reacendesse. A Bolívia continuava a armar-se. O Paraguai também. No início de 1937, iniciara entendimentos para comprar na Itália cerca de 40 a 50 aeroplanos, com financiamento do Banco Germânico, no valor total de US\$ 1,5 milhão, com taxa de juro de 7 ou $8 \%$ por mês, a ser pago em dois anos ${ }^{142}$. Porém, na opinião do Embaixador Spruille Braden, quem mais obstaculizou o processo de paz foi o Chanceler Carlos Saavedra Lamas, que intentou postergar qualquer acordo territorial até que pudesse assegurar ao máximo a influência da Argentina sobre o Paraguai e a Bolívia ${ }^{143}$. E não teve êxito. O acordo sobre transporte, firmado em 25 de fevereiro de 1938, entre os governos de La Paz e do Rio de Janeiro, objetivando à construção de ferrovia, ligando Santa Cruz de la Sierra (Bolívia) a Corumbá (Brasil), mediante a utilização de $£ 1$ milhão pendentes desde o Tratado de Petrópolis (1904), influiu, provavelmente para a concertação do Tratado de Paz de $1938^{144}$. Ele proporcionaria à Bolívia melhor enlace com o rio Paraguai e abriria o mercado brasileiro ao petróleo da região do rio Parapeti e adjacências, com o que a velha aspiração de Saavedra Lamas de adquirir para a Argentina seu exclusivo controle se frustrou ${ }^{145}$. A possibilidade de que a YPF viesse a explorar os campos petrolíferos, ao norte de Santa Cruz de la Sierra, invadindo a área da Standard Oil, chegou a entrar nos seus entendimentos com o Presidente da Bolívia, o Coronel David Toro, vinculado ao acordo para a construção, pela Argentina, da ferrovia Yacuiba-Santa Cruz de la Sierra ${ }^{146}$, concluído somente em 1941. Esta ferrovia, com visível caráter estratégico, interessava à Argentina, porque com ela esperava incorporar ao sistema econômico, e quiçá político, do rio da Prata a Bolívia, ou pelo menos, o oriente boliviano, a afastá-la do sistema do Pacífico. E o Chanceler do Paraguai, Carlos Zubizarreta, não escondeu sua desconfiança, ao ver que Saavedra Lamas o abandonava ${ }^{147}$. Ele percebera claramente, que a Bolívia lograra interessar não só a Argentina, como também o Brasil, fazendo-lhes promessas de concessões petrolíferas, que resultaram em acordos para a construção da ferrovia ${ }^{148}$. Com efeito, ambas as ferrovias - a que o Brasil construiria, de Corumbá a Santa Cruz de la Sierra, e a projetada pela Argentina, de Santa Cruz de la Sierra a Yacuiba passariam pelos campos de petróleo, de modo que os tratados firmados pelos dois países com a Bolívia tacitamente reconheceram a legalidade da desapropriação das reservas da Standard Oil, apesar das pressões contrárias dos EUA.

Naturalmente, os interesses econômicos e, sobretudo, a questão do petróleo não constituíram o único fator a determinar o comportamento da Argentina, tanto ao favorecer o Paraguai, durante o conflito, quanto no decurso da Conferência de Paz. Outras considerações militares e geopolíticas, de ordem estratégica, contribuíram também para que ela o sustentasse a qualquer custo. Independentemente do problema dos oleodutos, a presença da Bolívia, no Chaco, ao sul da 
Bahia Negra, não convinha à Argentina, dentro de seu plano de operações, na hipótese de uma guerra contra o Brasil, a qual ao sudoeste de Mato Grosso se estendesse. Séria ameaça configurar-se-ia para as suas forças ter à retaguarda território de um país, como a Bolívia, em cuja solidariedade política e militar confiar não podia ${ }^{149}$. Efetivamente, no seu Plan de Operaciones Máximo, o Estado Mayor General do Exército Argentino previa uma guerra, na qual, com efetivos da ordem de 260.000 homens, teria de enfrentar forças não só do Brasil (290.000 homens) como também do Chile (170.000 homens), Uruguai (40.000 homens), Bolívia (42.000 homens) e Paraguai (18.000 homens), um total de $560.000^{150}$. O Chaco e as províncias de Salta e Jujuy certamente seriam o teatro de operações, onde as forças do Paraguai e da Bolívia em combinação atuariam. Não era, porém, o Brasil e sim o Chile que se configurava como o "principal inimigo" da Argentina, segundo a percepção do seu Estado Mayor General ${ }^{151}$. Necessidade de expansão territorial o Brasil não sentia, nem na Argentina regiões havia "que puderan ser objetivo especial de su codicia”, salvo a Província de Misiones, cuja anexação, ao permitir-lhe o domínio de uma das portas de saída do Paraguai, possibilitar-lhe-ia aumentar consideravelmente a influência sobre este país ${ }^{152}$. Por outro lado, embora acentuasse que uma guerra promovida pelo Brasil provavelmente não assumiria "los caracteres de odio y de tenacidad”, o Estado Mayor General, em seu Plan de Operaciones Máximo, manifestava receio quanto à influência de outros países, "con intereses más arraigados y más graves”, como era o caso do Chile

"y, por sobre todos, de los EUA, que por sus incontenidas y pocas disimuladas actividades imperialistas, no han dejado en la Argentina - por su situación, sus fuentes de riquezas y su capacidad de progreso - la valla sudamericana más seria para la facil consecución de sus ambiciones, y que, para anularnos con manos ajenas no habrán de trepidar en acumular, estimular y ayudar enemigos en contra nuestra"153

Risco realmente houve de uma guerra, em que a Argentina tivesse de enfrentar simultaneamente o Chile e o Brasil. O Chile inesperadamente manifestara simpatia pela Bolívia, ajudando-a, e arrastou o Peru para semelhante posição, com o que a formação do Bloco do Pacífico se afigurou ${ }^{154}$. Conforme o General brasileiro Waldomiro Castilho de Lima, Inspetor do $1^{\circ}$. Grupo de Regiões Militares, reportou ao Conselho Superior de Guerra, esse "Bloco do Pacífico - Bolívia, Chile e Peru- e os interesses ali representados por vultosos capitais norte-americanos e que terão rendas fabulosas quando estiverem estabelecidos os transportes convenientes para o petróleo" eram antagônicos aos do Prata e certamente ofereceriam “certas restrições à expansão argentina após a guerra”155 . Esta não constituía, ademais, a única ameaça.

Àquele tempo, instável também se apresentava, internamente, a situação na Argentina. Políticos vinculados ao Partido Radical, do ex-Presidente Hipólito Yrigoyen, deposto em 1930, e alguns militares conspiravam e pediam à Bolívia que 
lhes fornecesse recursos e armamentos, com a promessa de apoiá-la, se vitoriosos, na guerra contra o Paraguai ${ }^{156}$. Diante de tais ameaças, tanto externas quanto internas, o Presidente Agustín P. Justo tratou de visitar oficialmente o Brasil a fim de aliviar as tensões e neutralizá-lo, evitando sua possível união com o Chile. Durante a visita ao Rio de Janeiro, onde recebeu efusivas manifestações de apreço e, inclusive, a patente de General de Exército brasileiro, ele firmou com o Presidente Getúlio Vargas vários convênios, bem como acordos e tratados, entre os quais o de Comércio e Navegação e um protocolo adicional, a solucionar o impasse em torno dos negócios de trigo e erva-mate. Do ponto de vista político, o mais significativo, a acompanhar o apelo dos dois presidentes para que o Paraguai e a Bolívia terminassem o conflito no Chaco, foi o Tratado Anti-Bélico de Não-Agressão e Conciliação, que a Argentina e o Brasil celebraram e ao qual outros quatro países - Chile (com ressalvas), México, Paraguai e Uruguai - logo aderiram ${ }^{157}$. A manobra do Presidente Justo surtiu, assim, efeito, pois o Chile recuou, conteve seus aparentes propósitos de intervir militarmente em favor da Bolívia e reatou as relações com o Paraguai. No final de 1934, a questão do Chaco, a complicar-se cada vez mais, tomou "rumo obscuro", segundo a expressão do Presidente Vargas, que começou a inquietar-se ${ }^{158}$. A Argentina sequer disfarçava seu apoio ao Paraguai, a provê-lo com todos os recursos, e acumulava tropas na fronteira com a Bolívia, em cujo território já ocupara alguns fortins e, conforme seu Ministro da Guerra, General Manuel Rodriguez defendia, seu propósito talvez fosse anexá-la, como parte desgarrada do Vice-Reino do Rio da Prata ${ }^{159}$. As tropas do Paraguai, por outro lado, atingido haviam a linha Murillo-Charagua ou Vanguardia-Salinas San José, visando a alcançar Santa Cruz de la Sierra e a cortar as ligações entre o Oriente boliviano e os centros populosos do Altiplano, através das rodovias Cochabamba-Santa Cruz de la Sierra (cerca de $700 \mathrm{~km}$ ) e Cochabamba, à confluência dos rios Chimoré-Ichillo (247 km). Se este objetivo se concretizasse, todo o polígono compreendido pelos rios Paraguai-Pilcomayo-Mamoré-Guaporé cairia sob a influência militar e, quiçá, política e jurídica do Governo de Assunção, o que embaraçaria a execução do plano de comunicações previsto no Tratado de Natal, firmado pelo Brasil com a Bolívia, em 25 de dezembro de 1928.

Este, por certo, não constituía o único problema. Outros - e mais graves igualmente adviriam para o Brasil. Caso chegassem a Santa Cruz de la Sierra, além de abrir o vale do Amazonas à infiltração da Argentina, as tropas do Paraguai, orientadas para objetivos econômicos, desceriam inevitavelmente o rio Mamoré e apossar-se-iam, na região de Cochabamba, das grandes reservas petrolíferas, que todos criam ali existir ${ }^{160}$. O perigo maior consistia, portanto, na perspectiva de que o Paraguai intentasse então incorporar à sua soberania todo o Oriente boliviano, para o que condições favoráveis existiam. Segundo o relatório do Capitão Aluizio Pinheiro Ferreira, Inspetor do Exército brasileiro na fronteira Mamoré-Guaporé, a população civil de Santa Cruz de la Sierra não mostrava qualquer alarme ante a 
possibilidade de que os paraguaios até lá avançassem ${ }^{161}$. Pelo contrário, os cruzeños ou bolivianos do Oriente muito mais com eles se identificavam, devido às suas origens étnicas e culturais, do que os collas, os bolivianos do Altiplano. Muitas vezes, contra o domínio político de La Paz já se haviam em armas levantado, pretendendo que Santa Cruz de la Sierra à Argentina se incorporasse, como uma de suas províncias. A última dessas reuniões fora abafada pelas tropas do General Hans Kundt, ex-Comandante em Chefe dos Exércitos bolivianos em operações no Chaco $^{162}$. E o Paraguai naturalmente estava a aviventar os ressentimentos e estimular a tendência de Santa Cruz de La Sierra à secessão, a acenar aos índios com a prometida propriedade das terras, que estes julgavam pertencer-lhes e "que lhes foram espoliadas pelos brancos, inclusive os brasileiros na zona fronteiriça, do Madeira à Bahia Negra"163 . No relatório apresentado ao Conselho Superior de Guerra, o General Waldomiro Castilho de Lima, Inspetor do $1^{\circ}$. Grupo de Regiões Militares, a observar que tal propaganda se baseava no aprismo ${ }^{164}$, "espécie de comunismo adaptado às condições daquela região”, acentuou que a independência de Santa Cruz de la Sierra e El Beni era "altamente prejudicial” ao Brasil, ao qual poderia trazer consequências fáceis de prever, dado que suas fronteiras, distantes e despovoadas, expostas estariam a toda sorte de saques e depredações, que poderiam desencadear hostilidades, motivadas pela reivindicação de territórios no Acre e de saída para o Amazonas ${ }^{165}$. Segundo ainda salientou, a independência de Santa Cruz de la Sierra e de El Beni, a desmembrarem-se da Bolívia, seria assim, sob o ponto de vista militar, "um perigo maior para a Amazônia”, porque o novo Estado "seria fatalmente" ligado ao Paraguai e, portanto, ao "principal inimigo provável” do Brasil: Argentina ${ }^{166}$. Por isso, diante de uma perspectiva que poderia forçar o Brasil a envolver-se no conflito para enfrentar a Argentina, o Presidente Vargas, a pretexto de retribuir a visita do Presidente Justo, viajou a Buenos Aires, em 1935, no momento em que o grupo de mediadores - composto pelos representantes dos EUA, Brasil, Argentina, Chile, Peru e Uruguai - lá se reunia, visando a encontrar solução para a guerra no Chaco. Casual não foi a coincidência. O que Vargas pretendeu foi intervir energicamente nas negociações e, mediante entendimento direto com Justo, compelir o Paraguai e a Bolívia a cessarem as hostilidades, retirando-lhes qualquer respaldo. Sem dúvida alguma, a concertação entre os dois presidentes e sua interferência nas negociações concorreram, decisivamente, para que os dois beligerantes, já exaustos e em situação desastrosa depois de dois anos de guerra, concordassem com a assinatura do protocolo de 12 de junho de 1935, que determinou o imediato cessar-fogo e convocou a Conferência de Paz, instalada em Buenos Aires.

A ameaça de que o conflito armado se reacendesse no Chaco e, aí, levasse a Argentina e o Brasil a um confronto direto diminuiu, porém não desapareceu. Vargas continuou a empenhar-se na aquisição de armamentos e conversou, pessoalmente, com o Presidente dos EUA, Franklin D. Roosevelt, quando este 
visitou o Brasil em 1936. A Argentina, informada, então, de que o Governo norteamericano arrendaria seis destroyers, protestou, fortemente, e tratou de evitar que a operação se concretizasse, a fim de manter a superioridade naval sobre o Brasil. Vargas ressentiu-se e as desconfianças quanto à futura política exterior daquele país se reanimaram, sobretudo porque, àquela mesma época, o Governo de Buenos Aires encomendara a Grã-Bretanha a construção de varias unidades para sua Marinha de Guerra ${ }^{167}$. Os Estados-Maiores do Exército e da Marinha, no Brasil, demonstraram então desassossego e tomaram várias medidas de alerta e de defesa nas fronteiras do Rio Grande do Sul e do Mato Grosso. Entretanto, na Conferência de Paz de Buenos Aires, o Chanceler da Argentina, Carlos Saavedra Lamas, obstaculizava de tal modo as negociações que o Embaixador brasileiro José de Paula Rodriguez Alves, Chefe da Delegação do Brasil, ironizou, ao dizer que ele incentivara as hostilidades para obter o Prêmio Nobel da Paz, que lhe fora conferido. Ao que tudo indicava, segundo a opinião do Embaixador dos EUA, Spruille Braden, Saavedra Lamas procurava aproveitar sua influência na Conferência de Paz, por modo que o Paraguai obtivesse com a redação do Tratado o que suas tropas não conseguiram na batalha: a zona de Bolívia onde comprovadamente petróleo existia. Aliás, ele propusera, inclusive, um plano para o desmembramento daquele país ${ }^{168}$ e suspeita houve de que influenciara o confisco das propriedades da Standard Oil, em 1937, pelo Governo do Coronel David Toro (1936-1937), o que naturalmente possibilitara a conclusão de um acordo com a Argentina ${ }^{169}$, vinculado à exploração do petróleo boliviano, para a construção de uma ferrovia entre Santa Cruz de la Sierra e Yacuiba, na Argentina. Este constituía o fundo da questão. O Brasil contraatacou, ao propor a construção de outra ferrovia, ligando Santa Cruz de la Sierra a Corumbá, no Estado de Mato Grosso. Mas receava que o controle pela Argentina das comunicações entre Santa Cruz de la Sierra e Yacuiba, ao mesmo tempo em que o Paraguai se propunha a construir também uma ferrovia na direção do ocidente, prendesse a Bolívia de tal forma que mais cedo ou mais tarde provocasse a secessão do Oriente boliviano. E a tal o Brasil opor-se-ia, indo até mesmo à guerra, se necessário ${ }^{170}$. Seria, para ele casus belli; pois não permitiria o desmembramento de qualquer parte da Bolívia, cujo estatuto territorial considerava "definitivo e não passível de quaisquer modificações”, na parte em que estava jurídica e formalmente definido, admitido ou reconhecido ${ }^{171}$. Em documento secreto, dirigido ao Ministro da Guerra, o General Pedro Aurélio de Goes Monteiro, Chefe do Estado-Maior do Exército brasileiro, ressaltou, aliás, que era de "capital importância” para o Brasil, que, "em hipótese alguma”, os limites territoriais do Paraguai, no Chaco, ultrapassassem o rio Negro ou Otuquis para o norte, a fim de não envolver a parte da margem direita do rio Paraguai, pertencente ao Estado de Mato Grosso ${ }^{172}$. Não sem razão, ele julgou que os fortins erigidos ao nordeste do rio Negro ou Otuquis poderiam constituir, em futuro próximo, novo limite "insidiosamente preparado pelo Paraguai para reivindicações do território por ele abrangido, como 
se atingido fosse no período de operações ofensivas”173 . E o Embaixador José de Paula Rodrigues Alves, Chefe da Delegação do Brasil à Conferência de Paz, reagiu, energicamente, quando o Chefe da Delegação do Paraguai, Gerónimo Zubizarreta, propôs a anexação ao seu território do triângulo de terra, que, situado à margem do rio Paraguai, o Brasil cedera à Bolívia, em 1904, e constituía, segundo o então Chanceler Oswaldo Aranha "a única alegação nossa para justificar a incorporação do Acre, sempre apontada como ato de imperialismo do Brasil"174 . Com efeito, essa proposta, se aceita e a cessão se concretizasse, invalidaria o Tratado de Petrópolis e por esta razão Aranha percebeu que se tratava de manobra, possivelmente insinuada por Saavedra Lamas, com o propósito de separar o Brasil da Bolívia, onde uma tendência em favor da recuperação do Acre ressurgia e propiciava as bases para uma aproximação da Argentina ${ }^{175}$. Saavedra Lamas, no entanto, não resistiu às pressões contrárias à sua presença como Ministro das Relações Exteriores da Argentina e Presidente da Conferência de Paz, realizada em Buenos Aires. O novo Presidente da Argentina, Roberto Ortiz (1938-1940) ${ }^{176}$, substituiu-o por José Luis Cantilo. E a Conferência de Paz, que, na opinião de Aranha, até então não passara de uma "querela pessoal”, uma competição de chanceleres, mais do que um esforço real para a terminação da contenda do Chaco, alcançou, finalmente, um desfecho, com o Tratado de Paz, Amizade e Limites, que o Paraguai e a Bolívia assinaram em 21 de julho de 1938. Contudo, nenhum dos dois países realizou, efetivamente, seus objetivos. Nem o Paraguai conseguiu capturar a zona do petróleo, no rio Parapeti e adjacências, nem a Bolívia pôde expandir seu território até às margens do rio Paraguai, onde obteve apenas um porto franco e o livre trânsito para suas mercadorias. Assim, os grandes vencedores, na guerra entre o Paraguai e a Bolívia, foram o Brasil e a Argentina. Ao firmarem os tratados de vinculação ferroviária, Santa Cruz de la Sierra-Corumbá e Santa Cruz de la Sierra-Yacuiba, estes dois países receberam enormes concessões para explorar um petróleo, que, conforme se comprovou, jamais em grande quantidade comercial apareceu.

\section{Notas}

${ }^{1}$ Mauá, 1942, pp. 171 e 177; Granzieira, 1979, pp. 117 e 118.

${ }^{2}$ Calógeras, 1927, p. 237; Normano, 1939, p. 230.

${ }^{3}$ Graham, 1968, p. 100; Mendoça, p. 206.

${ }^{4}$ Sodré, 1976, p. 262; Granzieira, 1979, pp. 62, 73 a 75.

${ }^{5}$ Donghi, 1972, pp. 168 e 274; Granzieira, 1979, pp. 58 e 60.

6 Mauá, 1942, p. 252.

${ }^{7}$ Mauá, 1977, pp. 116 a 119. 
8 Teixeira Soares, 1957, pp. 248 a 249, 297 a 298, 333 a 335; Faria, 1958, pp. 197, 225, 318 a 319; Normano, 1939, pp. 123 a 125.

9 Besouchet, 1978, pp. 107 a 114; Teixeira Soares, 1957, pp. 189 a 201; Mauá, 1942, pp. 301.

10 Id., pp. 295 e segs.

11 Mauá, 1942, p. 283; Teixeira Soares, 1957, p. 318.

12 Warren, 1978, p. 283.

13 Warren, 1985, pp. 51 a 61.

14 Ferns, 1969, p. 326.

15 Carta de E Thornton a Thomas Baring, particular, Rio de Janeiro, 23.2.1867; Thornton a Baring, particular, 7.9.1967. HC4.1.45, BBA-H.G.Lettson e Lord Claredon, Montevideo, 10.2.1866. PRO-FO420-20, Teixeira Soares, 1957, p. 309; Pomer, 1968, p. 237.

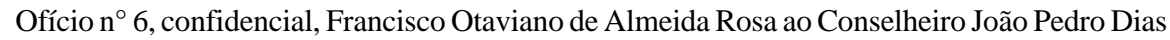
Vieira, Buenos Aires, 25.4.1965, AHI-272-1-21. Pomer, 1979, pp. 122 a 123. "Existe remédio radical e definitivo para a situação e este consiste em fazer com que o Paraguai e a Banda Oriental entrem para fazer parte de uma Federação com a República Argentina, a fim de criarem um Estado de língua castelhana que responda ao Brasil pelos seus atos e afaste por sua responsabilidade as ocasiões de guerra”. Nota de Domingo F. Sarmiento ao Ministro das Relações Exteriores da Argentina, New York, s/d, In Sarmiento, 1983, pp. 122 a 123.

17 Pastore, 1972, p. 178.

18 Memoria del Ministerio de Hacienda del Gobierno Provisorio al Congreso Nacional, Asunción, 24.11.1870. Apud Pastore, 1972, p. 178.

Caballero Aquino, 1985, p. 148.

20 Id., Ibid., p. 148 e 149.

21 Cardozo, 1965, p. 117.

22 Warren, 1985, p. 120.

23 Id. Ibid., pp. 32, 36 e 37.

24 Despatch $\mathrm{N}^{\circ}$ 4, W.Haggard to Marquess of Lansdowne, Asunción, 8.7.1904. PRO-FO59-62.

25 Id. Ibid. Warren, 1985, p. 126.

26 Despatch $\mathrm{N}^{\circ}$. 5, Haggard to Lansdwne, Buenos Aires, 10.8.1904; Telegrama, Haggard to Lansdowne, Buenos Aires, 12.8.1904, 1:45pm. Ibid.

27 Despatch Nº. 38, Cecil Gosling, British Consulate, to Foreing Office, Assunción, 30.9.1904. Ibid.

28 Id. Ibid.

29 Despatch N. 6, Haggard to Lansdowne, Buenos Aires, 24.8.1904. Ibid.

30 Despathc $\mathrm{N}^{\circ}$. 38, Gosling to Foreing Office, 30.9.1904. Ibid.

31 Ofício (minuta), Barão do Rio Branco, Ministro das Relações Exteriores do Brasil, ao Ministro Plenipotenciário em Washington, Alfredo de Moraes Gomes Ferreira, Rio de Janeiro. 30.12.1904. AHI-235/2/5.

32 Despatches Nº. 25, 28 e 34, Gosling to Haggard, Asunción, 19.8.1904, 26.8.1904 e 16.9.1904. PRO-FO5,962. Telegrama n. 30, expedido, Rio Branco a Gomes Ferreira, Rio de Janeiro, 12.11.1904; Ofícios (minutas), Rio Branco a Gomes Ferreira, Rio de Janeiro, 30.11.1904 e 14.4.1905. AHI-235/2/5.

33 Id. Ibid.

34 Ofícios, recebidos, Ferreira a Rio Branco, Washington, 12.7.1904, 23.9.1904, 30.9.1904 e 30.11.1904, AHI-234/1/3.

Moltmann, 1981, pp. 33 e 34.

36 Despatch Nº. 1, Gosling to Lansdowne, Asunción, 17.12.1904. PRO-FO59-62.

37 Id. Ibid.

38 Id. Ibid.

39 Warren, 1985, p. 133. 
Id. Ibid., p. 120.

Caballero Aquino, 1985, p. 214.

Id., Ibid.

Relatório Reservado sobre a Política Externa do Brasil e dos países da América do Sul, organizado por ordem do Ministro de Estado das Relações Exteriores pelo $1^{\circ}$. oficial da Secretaria de Estado, Ronald de Carvalho, do Gabinete do Ministro, Rio de Janeiro, 1927 - AHI.

\section{Id. Ibid.}

Id. Ibid.

Id. Ibid.

Carta de Orlando Leite Ribeiro, $1^{\circ}$. Secretário da Legação brasileira, ao General Pedro Aurélio de Goes Monteiro, Chefe do Estado Maior do Exército, confidencial, Buenos Aires, 16.1.1934 - AP51(7) - AN - APPAGM. Carlos Casado morreu em 1899 e seu filho, José Casado Sastre, ampliou ainda mais a companhia. Estabelecida já a sede em Puerto Casado, ele construiu Puerto Sastre e $250 \mathrm{~km}$ de ferrovia, em bitola estreita, adentrando o Paraguai. Vide Warren, 1985, pp. 210 e 211.

Carta de Orlando Leite Ribeiro ao General Goes Monteiro, confidencial, Buenos Aires, 16.1.1934 - AP51(7) - AN - APPAGM.

"Situação atual do Brasil como potência militar sul-americana" - Relatório apresentado ao Conselho Superior de Guerra pelo General de Divisão Waldomiro Castilho de Lima, reservado, Inspetoria do $1^{\circ}$. Grupo de Regiões Militares, s/d (provavelmente 1934) - AP51(5) - AN APPAGM.

“Situação do Brasil em face da Guerra do Chaco”, Ofício n. 107, secreto, 2ª Seção da Secretaria do Estado-Maior do Exército ao Ministro da Guerra, Rio de Janeiro, 27.11.1934. AP51(7) AN - APPAGM.

Ministério das Relações Exteriores - Protocolo entre o Brasil e a Bolívia firmados a 3 de setembro de 1925, edição reservada, Rio de Janeiro, Imprensa Nacional, 1926, pp. 18 e 24. Guilherme, 1959, pp. 42, 43, 328 e 329.

Vide artigo de Aniceto Solares publicado em El País, Sucre, 1926, apud. Osório, 1973, pp. 102 e 102.

Salum-Flech, 1972, p. 127.

Klein, 1968, p. 157; Antezana Villagran, 1981, pp. 16 a 18, 23 a 27.

Daniel Salamanca - Documentos para una historia de la Guerra del Chaco, apud. Querejazu Calvo, 1981, p. 37.

Nota, Luis F. Guachalla, Ministro da Bolívia em Assunção, a Gerónimo Zubizarreta, Ministro das Relações Exteriores do Paraguai, Asunción, 21.6.1931; Ofício nº 853, Zubizarreta a Guachalla, Asunción, 23.6.1931; Nota, Guachalla a Zubizarreta, Asunción, 29.6.1931; Ofício, Zubizarreta a Guachalla, 1.7.1931; Nota, Guachalla a Zubizarreta, 2.7.1931. In. Zubizarreta, 1974, pp. 216 a 219. Benitez, 1972, p. 371.

8 O cabo Libório talvez foi o único morto na refrega. Os soldados conseguiram escapar, protegidos pela semi-escuridão.

Lindolfo Collor - “La Facies Económica del Chaco”, La Prensa, 12.3.1933. Id. Ibid.

Nota, Juan de la C. Benavente ao Ministro dos Negócios Estranjeiros da Confederação Argentina, Buenos Aires, 22.8.1852. In Loza, 1936, pp. 12 a 22.

2 Nota, José Raimundo Taborga, Ministro de Relações Exteriores de Bolívia, ao Ministro dos Negócios Estranjeiros da Argentina, Laja, 6.7.1866. In Loza, 1936, pp. 28 e 29.

Carta, José Berges Aniceto Arze, Asunción, 31.1.1865. Copiador de Cartas Oficiais, AVRBSM-BN -1-22-12-2. Lobo, Eulália Maria Lahmeyer - “A importância Estratégica e Econômica da Província de Santa Cruz de la Sierra durante a Guerra da Tríplice Aliança” - Boletim de História, ${ }^{\circ}$. 6, Centro de Estudos de História, Rio de Janeiro, p. 16. 
Carta, Mariano Melgarejo a Francisco Solano López, Sucre, 3.8.1866. Apud Teixeira Soares, 1975, pp. 214 a 215. Vide também Quell, 1973, p. 233.

65 Cunha, 1975, pp. 128 a 135. Teixeira Soares, 1975, p. 224.

66 Vide Moniz Bandeira, 1985, pp. 255 e 256.

67 Benitez, 1972, p. 311.

68 Amayo, 1988, pp. 167 a 169.

69 Apud Querejazu Calvo, 1981, p. 1.

70 O Tratado de 1887 foi firmado pelo Enviado Extraordinário e Ministro Plenipotenciário da Bolívia, Isaac Tamayo, com Benjamin Aceval, Ministro das Relações Exteriores do Paraguai. O de 1894 coube ao enviado extraordinário e Ministro Plenipotenciário da Bolívia, Telmo Ichazo, negociar e firmar com o então Ministro das Relações Exteriores do Paraguai, Gregório Benitez. Vide - Salum Flecha, 1972, pp. 70 a 72, 84 a 90. Benitez, 1972, pp. 314, 315, 319, 320, 333 e 334.

72 Osorio, 1973, p. 5. Barrero U., 1979, p. 323.

73 “El Chaco Boreal Paraguayo - Su Incorporación a la Argentina”, s/d e s/a. AVP-AGN-A Legajo 7.4.5.10.

74 Id., Ibid.

75 Sobre a questão de limites entre a Argentina, Bolívia e Paraguai na região do Chaco vide Quesada, 1918, pp. 863 e 873.

76 Palmeiro, 1984, p. 74.

77 Circular n. 907, confidencial, Ministério das Relações Exteriores às Missões Diplomáticas Brasileiras, a) M.de A. (iniciais do Embaixador José Joaquim de Lima Silva Moniz de Aragão, Secretário Geral), Rio de Janeiro, 22.8.1934. AHI - Guerra do Chaco - 9(31).(43)5. Collor, Lindolfo - "La Facies Económica del Chaco”, La Prensa, 12.3.1933.

79 Id., Ibid. Warren, 1985, pp. 210 e 211. Seiferheld, 1983, p. 123. Palmeiro, 1984, p. 74.

80 Circular n. 907, confidencial, MRE às Missões Diplomáticas Brasileiras, a) M. de A. (Moniz de Aragão), Rio de Janeiro, 28.8.1934. AHI - Guerra do Chaco - 9(31).(43)5.

81 Querejazu Calvo, 1981, p. 185. Palmeiro, 1984, p. 74. “Próximo al estallido del conflicto con Bolívia, el predicamento y las influencias de la firma Carlos Casado Ltda. eran muy grandes en el Paraguai. Se trataba de la vinculación comercial de intereses más importantes entre Asunción y Buenos Aires. Desde Puerto Casado, donde se hallaban en forma intermitente los hijos del por entonces desaparecido pionero, hasta Buenos Aires, donde colaboraban abogados, yernos y otros parientes surgidos del tronco principal, se extendia un hilo de unión que tendria decisiva importancia durante el conflicto. La participación en la empresa de otros argentinos ligados a los centros del poder de la época añadia, por demás, un nuevo elemento que motivaria la simpatia y la asistencia argentinas hacia el Paraguay”.

82 Id., Ibid.

83 Osório, 1973, pp. 104 e 105. “O Chaco, e nele, particularmente, a zona marginal do rio Paraguai, acha-se muito afastado dos centros de população bolivianos, nada ou quase nada podendo a Bolívia invocar em seu benefício, a contentar-se com a posse exclusiva como base de suas reivindicações. Hoje mesmo, dispondo de recursos apreciáveis, a República do Altiplano, em toda a região, não consegue estabelecer mais do que fortins, os quais nem sempre passam de meros acampamentos”. Circular $n^{\circ}$. 907, confidencial, MRE às Missões Diplomáticas Brasileiras, a) M.de A. (Moniz de Aragão), Rio de Janeiro, 22.8.1934, AHI - Guerra do Chaco - 9(31).(43)5.

84 Klein, 1969, pp. 77. Seiferheld. 1983, pp. 456 a 458.

85 Id., Ibid., pp. 457 e 458.

86 Id. Ibid., p. 472.

87 Id., Ibid., pp. 472 e 473. Frondizi, 1955, p. 239.

88 Circular $n^{\circ}$.907, confidencial, MRE às Missões Diplomáticas Brasileiras, a) M. de A. (Moniz de Aragão), Rio de Janeiro, 22.8.1934. AHI - Guerra do Chaco - 9(31).(43)5. 
89 Despatch $N^{\circ} 208$, strictly confidential, Delegation of the USA - Peace Conference, Apruille Braden to the Secretary of State, Buenos Aires, 2.7.1936. Eclosure $N^{\circ} .1$ - Memorandum of conversation with Mr. Robert Wells, head of Standard Oil of New Yersey interests in Argentina and Bolívia. NA-724. 34119/521 - L/D.

90

91

92

93

94

95

96

97

98

99

100

101

102

103

104

105

106

107

108

109

110

111

Id., Ibid.

Id., Ibid.

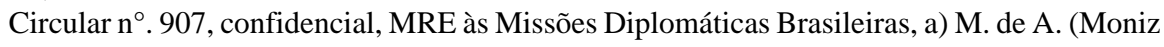
de Aragão), Rio de Janeiro, 22.8.1934. AHI - Guerra do Chaco - 9(31).(43)5. Id., Ibid.

Carta, confidencial, Orlando Leite Ribeiro ao General Goes Monteiro, Chefe do Estado-Maior do Exército, Buenos Aires, 16.1.1934. AP51 (7) - AN - APPAGM).

Id., Ibid.

"Situação do Brasil como Potencia Militar Sul-Americana" - Estudos Apresentados ao Conselho Superior de Guerra pelo General Waldomiro Castilho de Lima, Chefe da Inspetoria do $1^{\circ}$. Grupo de Regiões Militares, Reservado, s/d, provavelmente 1934. AP51(5) - AN - APPAGM. Solberg, 1979, pp. 13-14. Id., Ibid., pp. 37 e 38.

Larra, 1957, pp. 67 e 68.

Id., 1957, pp. 52 e 91

Solberg, 1979, pp. 48 e 49.

Seiferheld, 1983, p. 472. Solberg, 1979, p. 7.

Apud Larra, 1957, pp. 67 e 68.

Solberg, 1979, p. 56 e 123. Em 1930, seu contributo representou 57,9 \% do total da produção nacional e, embora caísse para 37,5 \% em 1934, ele continuou acima dos 40 \%, nos anos subsequentes, até superar os $60 \%$, a partir de 1940, enquanto a participação das companhias estrangeiras, da ordem de 42,1 \% em 1930 subiu para 62,5 \% em 1934, quando começou a declinar até cair para menos de $40 \%$ a partir de 1940. Frondizi, 1955, p. 368.

Id., Ibid., p. 54.

Id., Ibid., p. 54.

Id. Ibid., p. 55. Yergin, 1993, pp. 232 e 233.

Solberg, 1979, p. 211. Larra, 1957, pp. 124 a 133. Rouquié, 1981, p. 214.

Id., Ibid., p. 214.

Solberg, 1979, p. 154.

Id., Ibid., pp. 154 e 211. Rouquié, 1981, pp. 214 e 215. Frondizi, 1955, pp. 270 a 271.

Frondizi, 1955, pp. 389 a 391. Klein, 1969, p. 153.

Annual Report - 1931 - Doc. A3353/3353/33, confidential, Tottenham-Smith to John Simon Asunción, 30.4.1932. Paraguay - Chaco - 1933 - PRO-FO371-15852.

4 Annual Report - 1932 - 16269 Confidential, Tottenham-Smith to John Simon, Asunción, 29.3.1933 - Paraguai - Chaco, 1933 - A6093/1143/33. PRO-FO371 - 16586.

\section{Ibid.}

Vide íntegra do discurso in Seiferheld, 1983, pp. 498 a 501. Frondizi, 1955, p. 390.

Despatch $N^{\circ} .464$ - strictly confidential, Delegation os USA - Peace Conference, Spruille Braden to the Secretary of State, Buenos Aires, 22.7.1937. NA - File 724.34119.9.

Ibid. Sobre o tema vide Seiferheld, 1983, pp. 462 a 472. Klein, 1967, p. 229. Klein, 1969, p. 153. Warren, 1949, p. 294.

Seiferheld, 1983, p. 486.

Id., Ibid., pp. 464 e 465.

Id., Ibid., pp. 466 a 470. Warren, 1949, p. 294. Klein, 1969, pp. 217 e 218.

Spruille Braden fora quem, juntamente com seu pai, transferira algumas das concessões de petróleo que ela explorava. 
123 Despatch $N^{\circ} .464$, strictly confidential - Delegation of USA - Peace Conference, Spruille Braden to the Secretary of State, Buenos Aires, 22.7.1937. NA - File 724.34119/9. - “A seu debido tiempo, el Presidente del Directorio de Standard Oil de New Jersey me invitó a almorzar con él y sus directores (...) Después de alguna conversación general mi anfitrión, con considerable profanidad se soltó contra los ‘desonestos bolivianos que habian robado sus propiedades’ (de la Standard Oil). Le respondí qie estaba totalmente equivocado y que era la propia Standard Oil quien habia estado en falta en todo el negócio. En una forma más bién beligerante me pidió que le explicara. Le proporcioné todos los hechos y quando terminé de hacerlo, él se volvió al abogado de la Standard Oil, que estaba presente e le dijo: ‘Es esto verdad?’ La confirmación del abogado de mi historia resultó en mayor profanidad, esta vez dirigida a su propia plana mayor”. Braden, 1971, pp. 26 e 27.

124 “.... Ao citar Saavedra Lamas, é evidente que Spruille Braden reconhece nele o que vale dizer na Argentina -um inimigo da Standard Oil. Isso significa que Saavedra Lamas é um agente do inimigo real: a Royal Dutch Shell, que se aliou à Argentina no apoio oferecido ao Paraguai”. Chiavenato, 1979, p. 115. Sobre o tema vide Seiferheld, 1983, pp. 458 a 462. Klein, 1969, pp. 153 e 194.

125 Despatch Nº. 23, R. Noswosthy to Sir John Simon, La Paz, 9.2.1933; carta de Vickey Armstrong ao Foreign Office, London, 14.2.1933. PRO-FO371-16545.

126 Despatch $\mathrm{N}^{\circ}$. 1362, Atherton, US Embassy, to the Secretary of State, London, 12.4.1935; Despatches Nº 2233 224, US Legation in Asunción, 10.5.1935, Chronological Records Chaco Dispute - April 1st., 1935 to August 1st, 1935, p. 17. NA - File 724.34119/103 1/2.

127 Letters from Midlank Bank to Foreing Office, 1.10.1932 e 19.12.1932, PRO-FO371-1580. Despatch N. 105, R. H. Tollenham-Smith, Britsh Legation in Asunción, to H. G. Chilton, Britsh Embassy in Buenos Aires, Asunción, 22.11.1933. PRO-FO527 - 24.

128 Zook, 1962, p. 23.

129 Id., Ibid.

130 Estigarríbia, 1950, p. 195.

131 Palmeiro, 1973, p. 76.

132 Memorandum, Eusébio Ayala a Vicente Rivali, Embaixador em Buenos Aires, Asunción, 12.9.1934; apud Pastore, 1972, p. 395. Querejazu Calvo, 1981, p. 439. “En el Paraguay ya no cabian dudas acerca de la actitud de la Standard Oil, más aún con la presunción - que los hechos posteriores demostraron errada - de que el Chaco albergaba un reservatorio fabuloso en riqueza petrolera”. Seiferheld, 1983, p. 508. "La Standard Oil sabia entre tanto lo que los bolivianos iban a descubrir solo 30 años después: que los yacimientos disputados eran escasamente importantes. En consecuencia, no mostró mayor entusiasmo com los aprestos bolivianos”. René Zavaleta Mercado - “Bolívia: Crescimiento de la Idea Nacional”, Cuadernos de la Revista Casa de las Américas, La Habana, Cuba, 1967, apud Gonzáles Quintanilla, 1977, p. 30.

133 Memorandum, Ayala a Vicente Rivarola, Asunción, 12.9.1934, apud Querejazu Calvo, 1981, p. 439. Vide também Seiferheld, 1983, p. 509.

134 Solberg, 1979, p. 174. Seiferheld, 1983, p. 479.

135 Solberg, 1979, pp. 159 e 161.

136 Annual Report 1932 - 14249 confidential, Tottenham-Smith to John Simon, Asunción, 29.3.1933. PRO-FO16586 - Paraguay Chaco 1933 A6093/1143/33/.

137 Barrero U., 1979, p. 285.

138 Despatch $\mathrm{N}^{\circ}$. 208, strictly confidential, Spruille Braden to the Secretary of State - Delegation of USA - Peace Conference - Buenos Aires, 2.7.1936. NA 724.34119/521 LD. Braden, 1971, p. 31.

139 Despatch $N^{\circ}$. 594, strictly confidential, Braden to the Secretary of State - Delegation od USA - Peace Conference, Buenos Aires, 28.12.1937. NA-274. 34119/1158 LH. 
140 Nota de Protesto de la Delegación Boliviana - Enclosure $N^{\circ} .1$ to Despatch Nº.607, Braden to the Secretary of State, Delegation of USA - Peace Conference, Buenos Aires, 10.1.1938. NA724.34119/1173 LH.

141 Despatch $N^{\circ}$. 594, strictly confidential, Braden to the Secretary of State - Delegation of USA - Peace Conference, Buenos Aires, 28.12.1937. NA-724.34119/1158 LH.

142 Despatch $N^{\circ}$. 458, strictly confidential, Leslie E. Reed, 1rs Secretary, to the Secretary of State, Legation of USA in Montevideo, 21.1.1937. NA-724-34119/757 LH.

143 Braden, 1971, p. 91.

144 Só em 23 de julho de 1964, com a assinatura, em La Paz, do Protocolo Adicional ao Tratado de 1938 sobre a Ligação Ferroviária, o Brasil finalmente entregou a administração da Bolívia o trecho da ferrovia Corumbá - Santa Cruz de la Sierra, situado no território boliviano, e recebeu quitação do compromisso, que assumira com o Tratado de Petrópolis e o Tratado de 25 de dezembro de 1928 modificara. Ao negociar a entrega da ferrovia, os representantes brasileiros consideraram a importância geopolítica da região por ela servida. Relatório do Ministério das Relações Exteriores, apresentado ao Presidente da República, Marechal Humberto de Alencar Castelo Branco, pelo Ministro das Relações Exteriores, Vasco Leitão da Cunha - 1964 - Seção de Publicações da Divisão de Documentação do MRE, pp. 24 e 25.

145 Zook, 1962, p. 382.

146 Despatch $\mathrm{N}^{\circ}$. 464, strictly confidential, Braden to the Secretary of State, Buenos Aires, 22.7.1937. NA-File 724.34119/9.

147 Memorandum, Carlos Zubizarreta, Paraguayan Delegate. Enclosure to the Despatch of Oct. 7th., 1937, Buenos Aires. NA-724.34119/1081 LH.

148 Id., Ibid.

149 Circular Nº. 908, confidencial, MRE às Missões Diplomáticas Brasileiras, a) M. de A. (Moniz de Aragão), Secretario Geral, Rio de Janeiro, 22.8.1934. AHI - Guerra do Chaco - 9(31).(43)5.

150 Ministério de Guerra - Estado Mayor General del Ejército - Bases para el "Plan de Operaciones Máximo” - 1933-1934, secreto, Anexo a la Orden Secreta №. 66 - Ejemplar 1: Jefe. Plan de Operaciones Máximo - Variante A - Frontera Noreste - Zonas de Concentración - 1933-1934. a) General de Brigada Ramón Molina, Jefe del Estado Mayor del Ejército. Aprobado: General de División Tomás Martinez, Inspector General del Ejército. AN-AP51(9)-APPAGM.

151 Id., Ibid.

152 Id., Ibid.

153 Id., Ibid.

154 Ofício N. 107, índice: “Situação do Brasil em face da Guerra do Chaco”, secreto, Cel. Francisco Gil Castelo Branco, Chefe da $2^{a}$ Seção do Estado Maior do Exército, ao General Olímpio da Silveira, Chefe do Estado Maior do Exército, Rio de Janeiro. 27.11.1934. AN-AP51(7)APPAGM.

155 “Situação Atual do Brasil como Potência Militar Sul-Americana”. Estudos apresentados ao Conselho Superior de Guerra pelo General de Divisão Waldomiro Castilho de Lima, Inspetoria do $1^{\circ}$. Grupo de Regiões Militares, Reservado, s/d (provavelmente 1934-1935), AN-AP51(5) - HPPAGM.

156 Ofício $\mathrm{N}^{\circ}$. 237, Lafaiete de Carvalho e Silva ao Chanceler Afrânio de Melo Franco, Buenos Aires, 2.7.1933; Ofício N.304, reservado, Embaixada do Brasil no Uruguai (s/a) ao Chanceler Melo Franco, Montevideo, 3.10.1933. AHI- Lata 164, maços 2717 a 2722.

157 Atos Internacionais firmados por ocasião da visita ao Brasil do Excelentíssimo Senhor General Agustín P. Justo, Presidente da Nação Argentina, Rio de Janeiro, Tipografia do Jornal do Comércio, Rodrigues \& Cía., 1933.

158 Carta de Getúlio Vargas a Oswaldo Aranha, Rio de Janeiro, 24.12.1934 - CPDOC - GV 34.12.24/1. 
159

160 Relatório - Inspetoria dos CC/EE da fronteira Mamoré-Guaporé, a) Capitão Aluízio Pinheiro Ferreira, Inspetor - Comandante da 8a . Região Militar, 26 de janeiro de 1935. Índice: "Presta informações sobre as prováveis consequências da Guerra do Chaco nas relações brasileirobolivianas pela bacia amazônica”. AN-AP51(7) - APPAGM.

161 Id., Ibid.

162 Id., Ibid.

163 Id., Ibid.

164 Referência à Aliança Popular Revolucionária Americana -APRA, movimento de esquerda liderado no Peru por Victor Haya de la Torre.

165 “Situação Atual do Brasil como Potência Militar Sul-Americana” - Estudos apresentados ao Conselho Superior de Guerra pelo General de Divisão Waldomiro Castilho de Lima, Inspetor do $1^{\circ}$. Grupo de Regiões Militares, Reservado, s/d (provavelmente 1934-1935). ANAP51(5)APPAGM.

166 Id., Ibid.

167 Despatch $\mathrm{N}^{\circ}$. 372, Subject: Rumor regarding supposed intention of Argentina to attack Brazil. R. M. Scotten, Counselor of Embassy, to the Secretary of State. Rio de Janeiro, 3.4.1938. NA732.35/59 L/JPS.

168 I- Estados Unidos y la Paz del Chaco - II- EE.UU y la Carta de Belmonte (Memórias del Jefe de la Delegação Americana Spruille Braden. Capítulos XIX, XX y XXV. Tradução, Introdução y Comentários de Victor Andrade V., Cuadernos de Hoy, nº. 6, La Paz, 1982, p. 43.

169 Braden, Spruille - "Diplomáticos y Demagogos" - Memorias sobre la Conferencia de Paz del Chaco (Versión castellana de los principales capítulos), New York, 1971, p. 21. "El Gobierno norte-americano tenia razones para creer que la Argentina habia jugado un papel importante en la expropiación de los bienes de la Standard Oil llevado a cabo por el Gobierno boliviano el 13 de marzo de 1937... Después de la guerra, se celebraron negociaciones en Buenos Aires para una concesión petrolífera. Como contrapartida, la Argentina protegeria a Bolívia del Paraguay. La expropiación a la Standard Oil tuvo lugar no mucho después y luego breve lapso se firmó um acuerdo entre la Argentina y Bolívia que preveia la participación argentina en el desarrollo de los yacimientos bolivianos, como asi mismo la exportación de petróleo boliviano a la Argentina. (Cordell) Hull y Summer Welles estaban enfurecidos, particularmente no mucho antes el canciller boliviano Enrique Finot habia dicho al ministro norte-americano R. Heenry Norwel que 'Bolívia debe hacerle el juego al imperialismo argentino para obter un arreglo aceptable en el Chaco'”. Escudé, 1992, pp. 246 e 247.

170 Despatch $N^{\circ}$. 464, strictly confidential, Delegation of USA - Peace Conference, Spruille Braden to the Secretary of State, Buenos Aires, 22.7.1937. NA - File 724. 34119/9.

171 Nota $n^{\circ}$. 11, Embaixador Mario de Pimentel Brandão, Secretário Geral, a Alberto Ostria Gutierrez, Enviado Extraordinário e Ministro Plenipotenciário da Bolívia, Rio de Janeiro, 25.2.1938. AHI - Guerra do Chaco - Conferência de Paz.

172 Ofício nº.49, secreto 2a ${ }^{a}$. Seção, General de Divisão Pedro Aurélio de Goes Monteiro, Chefe do Estado-Maior do Exército, ao Ministro da Guerra, Rio de Janeiro, 4.6.1938. AHI - Guerra do Chaco - Conferência de Paz.

173 Id., Ibid.

174 Carta de Oswaldo Aranha a Getúlio Vargas, abril de 1938, CPDOC - FGV - 04 380405/2.

175 Id., Ibid.

176 O Presidente Ortiz, em 1940, licenciou-se, por motivo de doença, sendo substituido à frente do Governo pelo Vice-Presidente, Ramón S. Castilho. Em 1942, impossibilitado de reassumir, renunciou e, em 1943, os militares derrubaram o Presidente com um golpe de Estado. 
Resumo

Este artigo analisa as circunstâncias que envolveram a Guerra do Chaco, entre Paraguai e Bolívia, na primeira metade do presente século. Faz-se um estudo da evolução da situação política e econômica na região desde a Guerra da Tríplice Aliança, ressaltando também os interesses dos países vizinhos na disputa dos dois países beligerantes pela região do Chaco. Paraguai e Bolívia enfrentaram-se em torno da posse da região por motivos econômicos, sobretudo no caso do Paraguai, e por motivos estratégicos, precipuamente no caso da Bolívia que teria, com a tomada do Chaco, acesso à bacia platina e, assim, maior facilidade de escoamento para a sua produção petrolífera. A deflagração do conflito envolveu mais diretamente os interesses da Argentina e do Brasil, que tiveram importante papel no desenrolar e na conclusão da Guerra do Chaco.

\section{Abstract}

This article analyses the circumstances that surrounded the Chaco War, between Paraguay and Bolivia, in the first half of the current century. It studies the evolution of the political and economic situation in the region since the War of the Triple Alliance, stressing also the interests of the neighbouring countries in the dispute of the belligerent countries over the Chaco. Paraguay and Bolivia fought each other in order to control the region guided by economic reasons, mainly for Paraguay, and strategic ones, mostly for Bolivia, which, by possessing the Chaco, would have access to the Plata Basin and easier drainage to its oil production. The deflagration of the conflict involved more directly the interests of Argentina and Brazil, two countries that played an important role in the development and in the conclusion of the Chaco War.

Palavras-chave: Guerra do Chaco. Paraguai. Bolívia.

Key-words: Chaco War. Paraguay. Bolivia. 